\title{
w w
}

A.

LBL-4430 c. 2 $X$ ERG-76-09

KRAFTVARME ÅNGTURBINER 20-50 MW

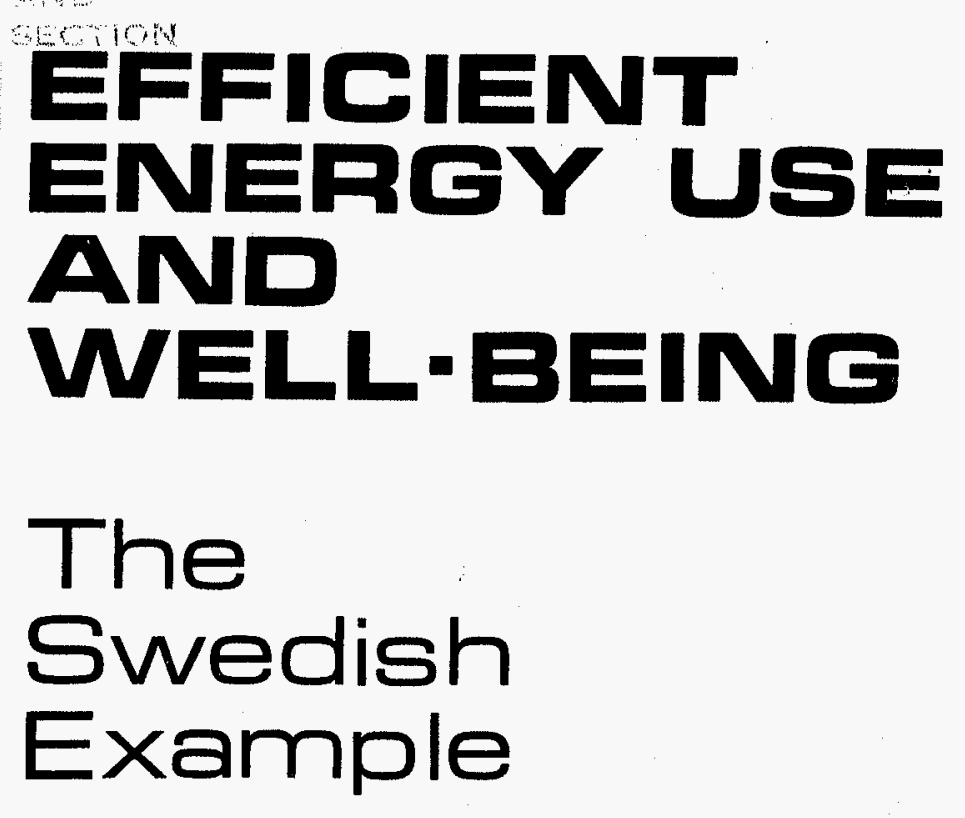

Lee Schipper

A.J. Lichtenberg

Energy and Environment Division Lawrence Berkeley Laboratory University of California Berkeley, California 94720

\section{TWO-WEEK LOAN COPY}

This is a Library Circulating Copy which may be borrowed for two weeks. For a personal retention copy, call Tech. Info. Diuision, Ext. 5545

\section{April 1976}

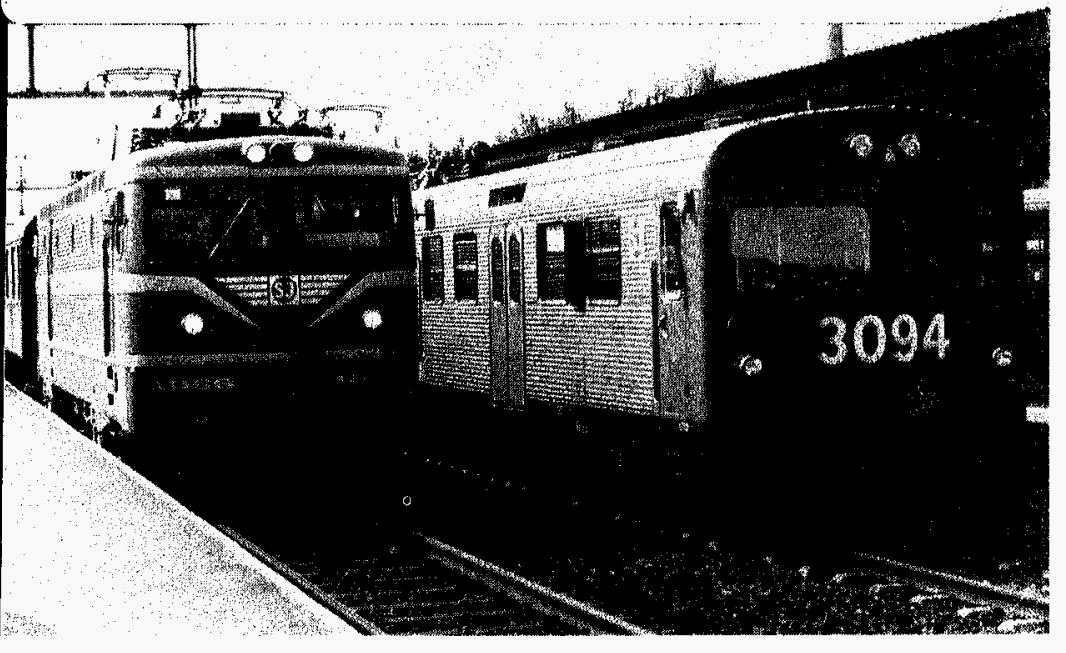


To be submitted for

LBL -4430

publication

ERG $-76-09$

EFFICIENT ENERGY USE AND WELL BEING

THE SWEDISH EXAMPLE*

L. Schipper $\$$

A.J. Lichtenberg ${ }^{\pi}$

Work done under

U.S. Energy Research and Development Administration

Contract W-7405-ENG-48

* This work was supported in part by the Energy and Environment Division of the Lawrence Berkeley Laboratory with Funds provided by the Energy Research and Development Administration. Opinions are solely those of the authors.

$\S$

Energy and Resources Group and Lawrence Berkeley Laboratory, University of California, Berkeley, California. Also supported by a stipend from the Society for the Advancement of Scandinavian Studies.

I

Chairman, Energy and Resources Group, University of California, Berkeley, California.

Please address correspondance to the authors at

Room 100, Building T-4

University of California

Berkeley, CA 94720 


\section{ACKNOWLEDGMENTS}

This is the first in a series of international energy use and policy comparisons. One of us (L.S.) thanks the Society for the Advancement of Scandinavian Studies for generous support during 1975. We also would like to thank many individuals who made their time and data available to us, including Drs. Bo Carlsson, Bertil Eneroth, Mats Höjeberg, Lars Kristofferson (in Sweden), Måns Lönnroth (Secretariat for Future Studies), and Hans Grönwa11 (Swedish Embassy) who coordinated our data collection and arranged many contacts for us, and Drs. Andreas Doernberg, Joe1 Darmstadter, Jeff Milstein, Steve Carhart, Clark Bullard, David Pilati, Bruce Hannon, Robert Herendeen, Arthur Rosenfeld, Eric Hirst, John Moyers, Steven Dole, Richard Norgaard, and James Just (in the U.S.), who provided assistance, data, or comments during the last year. Above all, our thanks to Drs. Jack Hollander, Mel Simmons, and Bob Budnitz of the Energy and Environment Division of LBL and Dr. John Holdren of the Energy and Resources Group, University of California, for their encouragement. Mr. Bob Stevens of LBL provided the graphics, while Mr. Bob Barton assisted with the editing and provided the railway photos. Tack så mycket!

\section{COVER PHOTOS}

FRONT

(Upper Left) -- One of several oil-fired plants producing both eleatricity. and district heat in Malmö (see Fig. 6).

(Lower Right) -. A Stockholm district local train terminating at Märsta being passed by a longer-distance northbound train. Passengers an ride the district train to here on their unlimited-ride monthly passes, then only have to buy an additional ticket for the rest of their journeys' distance.

BACK -- A steam powered local from Söderhamn, having joined the electrified main line, is here at Lenninge enroute to Bollnäs in the winter of 1948. Diesel locomotives have since replaced steam on unelectrified lines. 
EFFICIENT ENERGY USE AND WELL-BEING:

THE SWEDISH EXAMPLE

Lee Schipper and A. J. Lichtenberg

Energy and Environment Division

Lawrence Berkeley Laboratory

and

Energy and Resources Group

University of California

Berkeley, California 94720

\section{ABSTRACT}

A detailed comparison is made between the per capita energy consumption in the U.S. and Sweden. Sweden uses between $55 \%$ and $65 \%$ of the per capita energy (depending on the way hydro-electricity is counted) at essentially the same per capita income. It is shown that this difference arises both from differences in the mix of economic activities and from the differences in the energy consumption per unit output of these activities. The most important contributions to the differences in energy use arise from higher efficiencies in transportation, materials processing, and space heating in Sweden. Differences in the mode mix in transportation, particularly the reliance on the automobile in the U.S., also contribute significantly to the lower Swedish energy use. The more severe Swedish climate substantially increases the need for space heat relative to the U.S., obscuring dramatic differences in space heating efficiencies. Energy costs have played an important role in creating a more energy efficient economy in Sweden, aided by institutional and cultural factors. The comparison suggests that more efficient energy use will not interfere with and can in fact improve the functions of the United States economy over the long run. 
CONTENTS

I. Introduction . . . . . . . . . . . . . . . . . . . 3

II. General Observations Regarding Energy Use and Intercountry Comparisons . . . . . . . . . . . . . . 4

III. Sweden and the United States: Physical and Economic Comparisons . . . . . . . . . . . . . . . 10

IV. Comparison of Energy Use in the United States and Sweden . . . . 11

A. Transportation . . . . . . . . . . . . . . . 15

B. Residential and Commercial Energy Use . . . . . . . . . 22

C. Industrial Energy Use . . . . . . . . . . . . . . 27

D. Imports and Exports of Goods . . . . . . . . . . . 37

V. Analysis of Energy Differences and Conclusions. . . . . . . . 37 Footnotes and References . . . . . . . . . . . . . . . . . 43 Appendix - Discussion of Electricity Production and District Heating . . 49 


\section{INTRODUCTION}

Although it is often said that a direct relationship exists between per capita energy use and standard of living, as measured by Gross National Product $(1,2)$, examination of the energy and GNP statistics for the most industrialized countries indicates a large spread in the ratio of energy use per unit of GNP (see Fig. 1). This article compares energy use in the United States, one of the countries with high energy use per unit of GNP, with that in Sweden, a country which in 1971 used approximately 60\% as much energy as the U.S. to generate each dollar of GNP. Sweden was chosen not only because of its low energy to GNP ratio, but also because the GNP per capita is essentially the same in both countries. Moreover, much of the economic activity and many of the demographic features are similar to those in the United States. Thus evaluating the differences in energy utilization between these two countries may illuminate strategies for saving energy.

Studies of energy conservation in the United States indicate that the more important of these strategies, taken together, could reduce energy consumption $25-40 \%$ (3-5), while lowering pollution (4), reducing capital requirements for energy production (4), and generally raising employment (4). But the interrelationships among economic inputs including energy within an economy are complex. Thus examination of an economy that requires substantially less energy than our own may provide guidance in understanding the total effect of energy conservation.

Interest in energy use and conservation has stimulated a number of international comparisons $(6,7)$ as well as new evaluations of data from within single countries $(8,9)$. A preliminary study concerned with a number of countries shows some of the differences reported here without drawing conclusions (10). A study of the U.S. and West Germany developed comparisons further, discussing methodologies, and obtaining conclusions concerning possibilities for energy conservation in the U.S. in qualitative agreement with our Section V (11). Two other comparisons of U.S. and Swedish energy consumption differences have been undertaken $(6,7)$, and we are grateful to have been able to compare our data with theirs. Although there are many small discrepancies in data from different sources, in no cases are these discrepancies large enough to change our general conclusions.

Except where popular use dictates American units (e.g., miles per gallon, deg-days Farenheit) we use kilowatt-hours as our standard unit; kWh means fuel 
or electricity used in end consumption; $\mathrm{kWh}$ e refers to electricity only, while $k W h_{t}$ refers to total consumption of energy with electric conversion losses included at the rate of approximately $2 \mathrm{kWh}$ lost per $\mathrm{kWh}$ produced. All tons are metric.

II. GENERAL OBSERVATIONS REGARDING ENERGY USE AND INTERCOUNTRY COMPARISONS Many factors enter into the determination of the ratio of energy use to GNP. Among these are energy costs relative to other costs, government policies including taxes, subsidies and regulations, and demographic and cultural variables. These factors combine to set a price for energy relative to other goods and services. Changes in energy use can, in principle, be determined from the elasticity coefficients for the demand for energy with respect to a set of independent variables.

Although a set of independent variables is difficult to define, it is genera11y agreed that the price elasticity of demand is a meaningful econometric quantity. The elasticity of demand $e$ is usually defined as the percent change in demand that occurs when the price changes by one percent. One must distinguish, however, between short run and long run elasticities. Over a short period most responses to price are generally inelastic, i.e., the percentage change in energy consumption is smaller than the percentage change in price, while on a longer time scale many goods tend to be price-elastic. For example, if the cost of residential heating rises substantially, then in the short run householders will turn down their thermostats slightly and be more careful with ventilation, etc., to effect energy savings; but it is only over a long period of time that better insulation and other major energy saving designs, manifested primarily in new dwellings, will produce large energy savings. Econometrically determined long term elasticities are generally found to be substantial. A study of the long term elasticity of electricity in the U.S., for example, gave $e=1.2$ for residential use, $e=1.8$ for industrial use, and $e=1.4$ for commercial use (12). Recent.studies for gasoline indicate the long term elasticity may be as high as 0.75 (13).

The long run effects of energy prices can be seen qualitatively in Fig. 1. The "high" energy/GNP countries are those that historically have had cheap energy (relative to other goods and services); the U.S., Canada, Great Britain, and Norway (depending on how one counts the contribution of hydropower) are examples. 


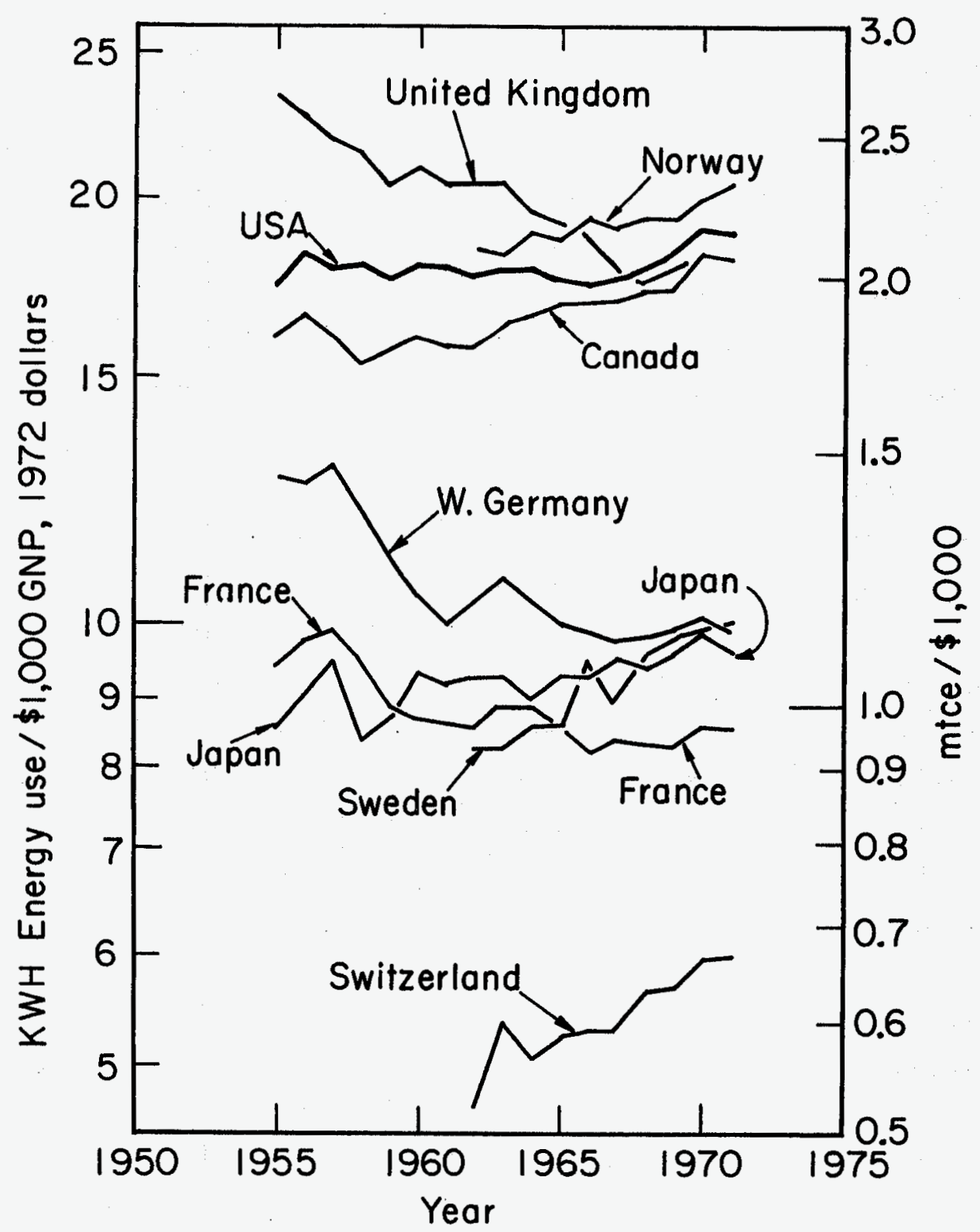

XBL7512-9188

Fig. 1. The energy/GNP ratio for several countries over time, with hydro power counted at $3 \mathrm{kWh}_{\mathrm{t}} / 1 \mathrm{kWh}$. From Linden (1). 
The countries with lower energy/GNP ratios are those that have been relatively fuel poor, especially since World War II. Although Sweden, for example, has had ample hydropower, the country has been increasingly dependent on imported petroleum. Consequently electricity has been inexpensive relative to fuel, with both price and per capita consumption very similar to that in the U.S. Motor fuels, on the other hand, have been taxed heavily in Sweden and consequently per capita consumption of these refined petroleum products has been far below the consumption in the U.S. Similar taxes have been the rule in other oil-poor countries. Although oil for home heating has been relatively inexpensive in Sweden (comparable to U.S. oil prices) the large amounts demanded for long winter heating seasons acted in place of higher prices to stimulate conservation efforts $(14-18)$.

One factor often said to be of great importance in determining the energy/ GNP relationship is the relative industrialization or type of industry in a country. Certain products are particularly energy-intensive, including steel, aluminum, cement, paper, and plastics. The effect of changing the output mix is most noticeable in comparing Luxembourg, where the steel industry plays a dominant role in the economic structure, with Switzerland, where banking, insurance, timepieces and other items of high value-added per $\mathrm{kWh}$ predominate. Luxembourg has an energy/GNP ratio of $\left(51 \mathrm{kWh}_{t} / \$\right)$ compared to Switzerland's $\left(10.3 \mathrm{kWh}_{t} / \$\right)(10)$. An earlier comparison of Great Britain and New Zealand noted a factor of two between the energy/GNP ratios of these countries (5), part of which may be attributable to the degree of wealth based on agriculture in New Zealand. However, this effect is usually small among industrialized nations, as can be seen if the percentages of the GNP's of the countries in Fig. 1 in the agricultural, industrial, and service sectors are compared. The agricultural sectors are between $3-5 \%$ of the total GNP for most of the countries considered; if any correlation exists, it is between energy use and the services sector, which will be explored further in the specific U.S. - Sweden comparison below.

The effects of cultural and lifestyle differences on energy consumption are very difficult to quantify, but these effects are clearly very important. Cultural patterns, although not wholly controlled by the marketplace, may be tempered over long periods of time by prices and fuel availability. Some of the current intensive energy use patterns in the United States and Canada can be traced to the availability of fuel wood during the 19 th century (19). In 
1850, for example, with a per capita energy consumption of $30.8 \times 10^{3} \mathrm{kWh}$, including wood, the U.S. used as much energy per capita as Switzerland does today.

In comparing ratios of energy use to GNP, several methodological problems arise. Comparing the size and content of the gross national product has received considerable attention (20). In our study we give indications of the structure of the economy in Sweden and in the United States, highlighting the differences and similarities. Accounting for differences in climate, geographic factors, population distribution, etc., is also important; we have made comments on this problem where applicable. The problem of counting the contributions of hydroelectric power and of combined electricity/heat generation are thought to be important in international comparisons, and are treated in the Appendix. We find that no matter how one counts hydropower the difference in energy use between Sweden and the U.S. is large, especially since the largest contrasts appear in transportation, space heating, and process heat applications. The use of non-commercial sources of energy, usually considered only when discussing less developed countries, are important to our work because the paper industry in Sweden, which accounts for fully $13 \%$ of the total consumption of energy there, actually generates $60 \%$ of its fuel internally from waste forest products. Together with other waste products, including urban wastes, these non-commercial fuels account for 9\% of Sweden's total fuel use in 1971.(21). Finally, a troublesome statistical problem is inconsistency between different information sources; for example, the fuel used by agricultural and construction equipment could be counted in transportation, or industry, depending on how figures are kept. Similarly self-generated electricity, district heating, by-product fuels (such as coke gas), non-commercial fuels, consumption of energy by energy producers, and so forth must be carefully sorted out. In this paper we believe we have resolved these various problems to the point that the remaining errors are only a few percent. 
Table 1. Basic economic and social indicators for the U.S. and Sweden (1971).a

Physical Characteristics:

$\begin{array}{rc}\text { U.S. } & \text { Sweden } \\ 207 & 8.1 \\ 57 & 47 \\ 5,500 & 9,200\end{array}$

Economic Activity:

GDP (current \$/capita)

Energy consumption

(kWh /capita)

5,051

4,438

Stee1 (kg/capita)

96,000

52,450

Cement (kg/capita)

620

680

Fertilizer (kg/capita)

342

430

Paper (kg/capita)

105

67

224

540

Food (per day):

kcalories/capita

3,300

2,850

Protein (g/capita)

99

80

Cereals (g/capita)

176

168

Meat ( $g /$ capita)

310

142

Health, Education:

Doctors/1000 persons

1.5

1.35

Dentists/1000 persons

0.49

0.72

Hospital beds/1000 births

7.8

15

Infant deaths $/ 1000$ births

19

11.1

Teachers/1000 students

34

60

Newspaper copies/1000 persons

301

Books published/1000 persons

0.39

534

Conveniences:

Telephones/capita

Television sets/capita

0.59

0.56

Autos/capita

0.45

0.32

0.45

0.3

Passenger-miles/capita (1970)

7,900

5,050

Refrigerators

(\% saturation of households)

100

93 
(Table 1 , continued)

Freezers (\% saturation

of households)

$\frac{\text { U.S. }}{28} \quad \frac{\text { Sweden }}{46}$

Clothes washers

( $\%$ saturation of households)

76

41

Vacuum cleaners (\% saturation of households)

88

89

${ }^{a}$ Sources: U.S. Data from USSA (24), Swedish data from SEB (22), $S \AA$ (23), and fact sheets distributed by the Swedish Institute. 
III. SWEDEN AND THE UNITED STATES: PHYSICAL AND ECONOMIC COMPARISONS

We take the years $1970-1972$ as our comparison period, because complete data are available and because energy prices and use trends were relatively stable compared to the post embargo period. Where appropriate we used data from other years. 1971 was a mild recession year for Sweden; total energy use was slightly higher in 1970, from which our Swedish industry statistics were taken. Unless otherwise noted we use the old exchange rate of 5.18 Swedish Crowns (skr) per dollar. This rate was as 1 ow as $3.92 \mathrm{skr} / \$$ in 1973 and has stabilized at $4.38 \mathrm{skr} / \$$ in $1975(22,23)$.

In Table 1 we compare physical characteristics, economic activity, and various measures of well-being in the U.S. and Sweden. Although the populations differ by a factor of 25, the population densities are similar, as is the distribution into fairly populated urban centers and sparsely populated rural regions. Movement to the suburbs, fostered by the automobile, started earlier and is more advanced in the U.S., although there are signs of such a trend in Sweden $(25,26)$. The natural distances over which goods must move is larger in the U.S., although in Sweden much of the lumber, iron ore, and electric power flows from the sparsely populated far north to the more crowded south. The climate in Sweden is more severe than in the U.S., in the sense that the number of degree days (based on $68^{\circ} \mathrm{F}$ ) is far larger, varying from 7700 in the extreme south to over 12,000 in Norrland (17). We have estimated that the average number of degree days, weighted by population distribution, is close to 9200 in Sweden, thus comparable to North Dakota, while the weighted U.S. average is approximately 5500 degree days (27).

Economic activity indicates that in 1971 the U.S. had a $10 \%$ higher GNP per capita than Sweden $(22-24)$ at the then current exchange rates (see Table 1). The striking difference, however, is the fact that for each dollar of GNP Sweden required only $60 \%$ (1971) as much energy as the United States. Subtracting the energy content of non-fue1 imports and exports (see following) reduces the 1971 Swedish figure to $55 \%$. Despite the lower energy use we note that the total per capita production of basic industrial commodities is quite comparable in Sweden and the United States.

Basic well-being is difficult to compare quantitatively. As seen in Table 1, food intake is similar, with Americans characteristically eating considerably more meat (about twice the Swedish per capita consumption), which per gram of protein is more energy-intensive than most other foods. In health 
and education, Sweden leads the U.S. in almost all categories. When the comprehensive health and social security system in Sweden is examined this difference is even more striking.

The large number of autos and TV's in the United States is accounted for mainly by multi-unit ownership by families. Transportation convenience is, in fact, quite comparable, because public transportation is more readilly available in Sweden, while domestic distances are generally smaller. Sweden has also developed a very popular charter air travel system that provides low cost packaged tours to most of the popular tourist spots in southern Europe and Africa. Swedes have far more second homes (500,000 in al1) per capita than Americans, and most of the population enjoys four weeks of paid vacation each year. Thus we conclude that the living standards are quite comparable quantitatively in Sweden and the U.S., but the mix is substantially different, emphasizing somewhat less energy-intensive economic activities and life styles in Sweden.

IV. COMPARISON OF ENERGY USE IN THE UNITED STATES AND SWEDEN

In Table 2 we compare energy use in the U.S. and Sweden. This table is further amplified in Figs. 2 and 3, in which the flows of fuel to each end use sector are shown. Sweden uses less energy per capita in all sectors, the largest difference being in the transportation sector. Considerable differences also exist in basic materials processing in the industrial sector, and in electricity use in the residential and commercial sector. We sha11 examine these differences in greater detail below.

A useful formula that summarizes the uses of energy ( $\left.\mathrm{T}_{\mathrm{J}}{ }^{\prime} \mathrm{s}\right)$ is: energy use $=\Sigma_{J} E_{J} D_{J}=\Sigma E_{J}^{\prime} D_{J}^{\prime}=\Sigma T_{J}$, where the $D_{J}$ are the final dollar demands for goods and services, and the $E_{J}$ are the energy intensities of those demands; or, in physical terms, the $D_{J}^{\prime}$ are the quantities of goods and services, and the $E_{J}^{\prime}$ the energy intensities associated with those quantities.

When data are disaggregated in this way, both the relative mix of modes (the $D_{J}$ or $D_{J}^{\prime}$ ) and the efficiency of those modes $\left(E_{J}\right)^{-1}$ or $\left(E_{J}^{\prime}\right)^{-1}$ can be compared among countries. Energy use in the economy can be lowered both by shifting to less energy intensive $D_{J}$ and/or by increasing the efficiency (lower $E_{J}$ ) of production of a given $\mathrm{D}_{\mathrm{J}}$. We shall use this formalism in the specific comparison of U.S. - Swedish energy use to follow. The above equation, however, can distort the comparison of energy efficiencies, because demographic differences affect 
APPROXIMATE FLOW OF ENERGY THROUGH

THE UNITED STATES ECONOMY, 1971

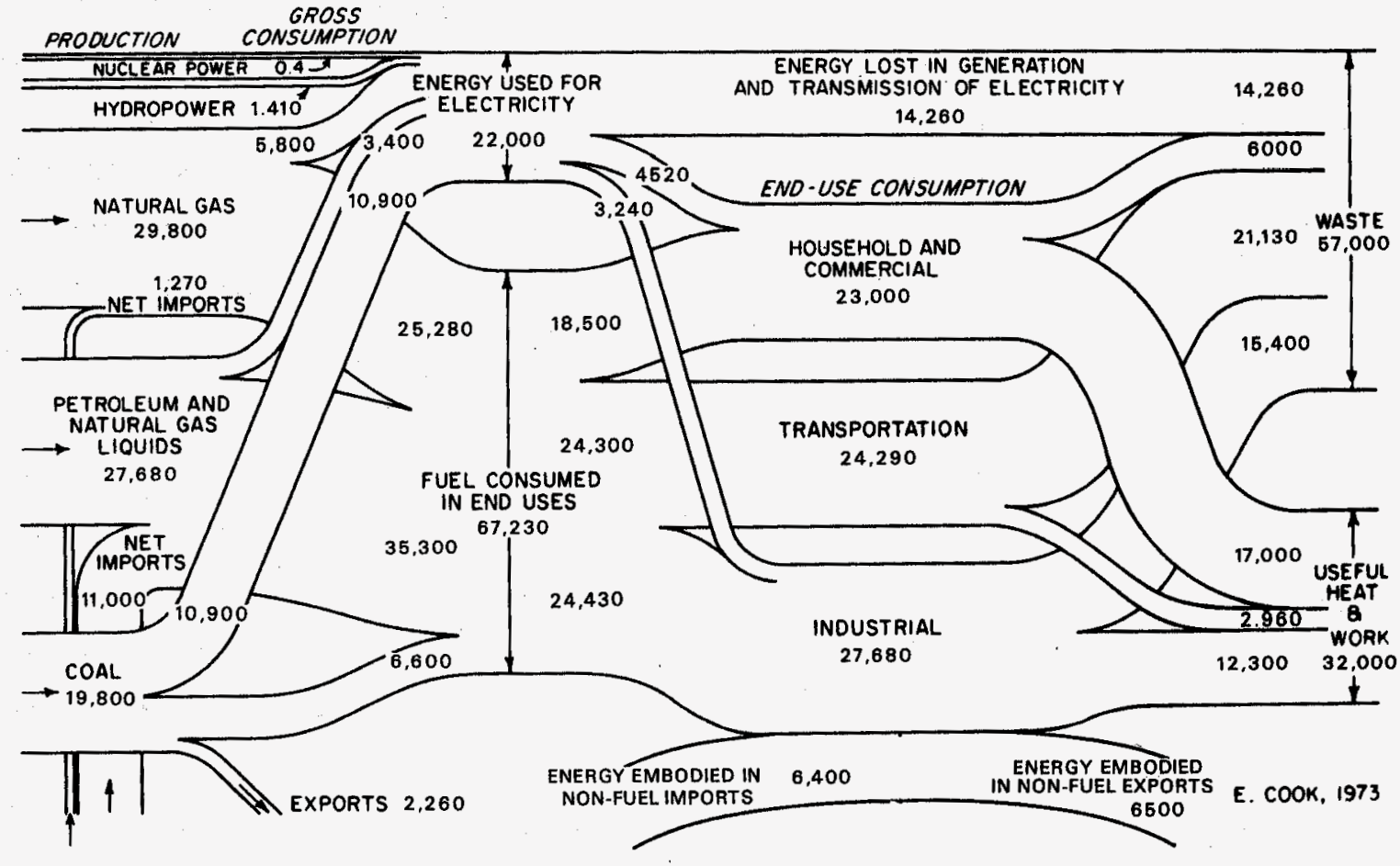

xBL761-5009

Fig. 2. Energy flow diagram for the U.S. All figures in kWh per capita. Import/export balance via non-energy goods estimated from Ref. (35) excludes process energy for refined imported fuels (ca $1800 \mathrm{kWh}$ per capita in 1971). Excludes wood wastes ( $1000 \mathrm{kWh}$ per capita) and feedstocks. 


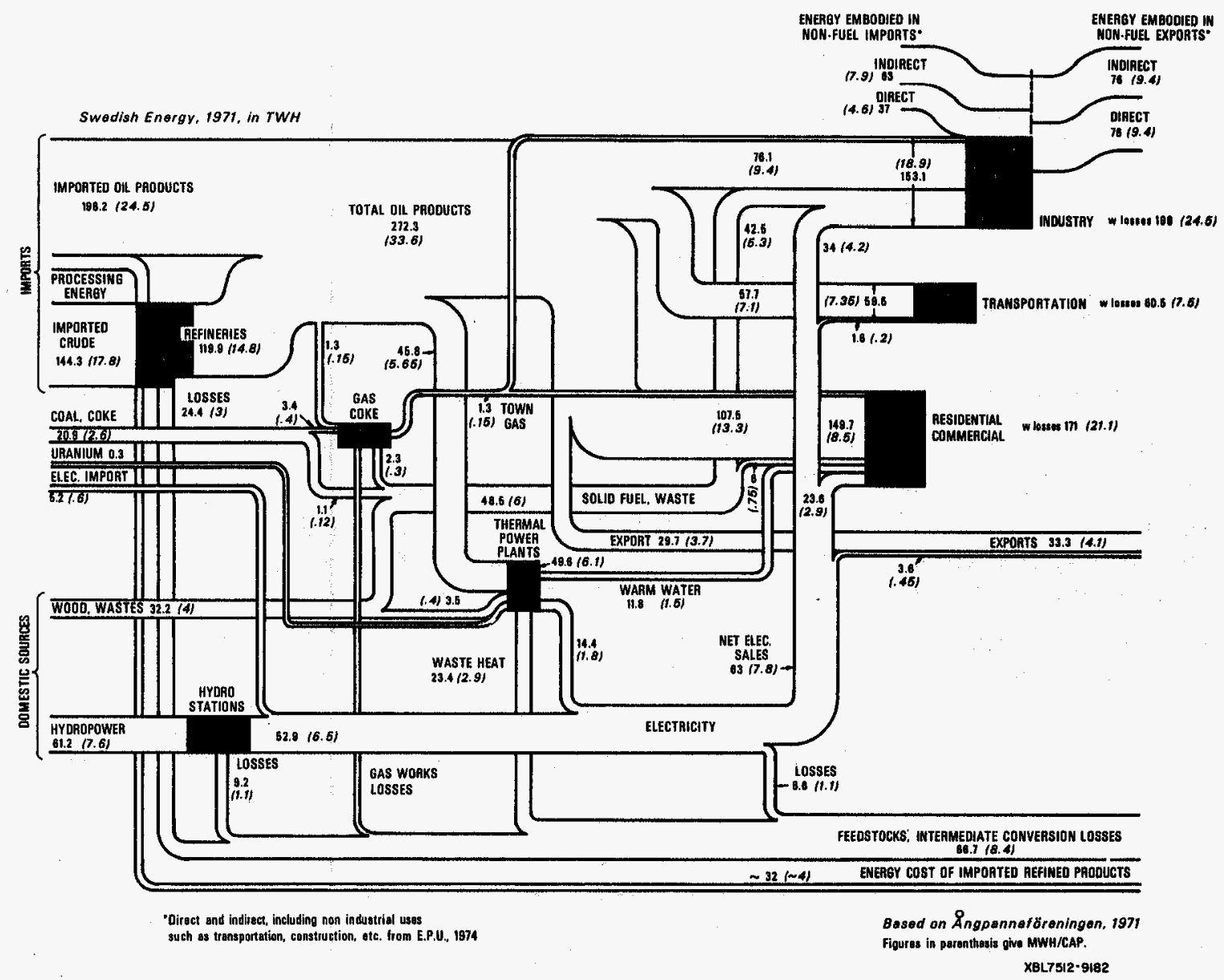

Fig. 3. Energy flow diagram for Sweden, 1971. Figures are in $\mathrm{TWh}\left(=10^{9} \mathrm{kWh}\right)$; figures in parentheses are MWh per capita figures, "With Losses" figures calculated by assuming $1.6 \mathrm{kWh}_{\mathrm{t}} / \mathrm{kWh}_{\mathrm{e}}$. Import/export via trade from $\mathrm{EPU}$ (16) (excluding the energy cost of refined imported products, shown in the lower right hand corner). Other data from IVA (21). Figure based on one drawn by Angpanneföreningen (31). Note the losses in hydropower. 
Table 2. Energy consumption in kWh/capita for U.S. and Sweden in 1971.

\begin{tabular}{|c|c|c|c|c|c|c|}
\hline & \multicolumn{3}{|c|}{ United States ${ }^{a}$} & \multicolumn{3}{|c|}{ Sweden $b$} \\
\hline & $\mathrm{kWh}$ & $\mathrm{kWh}_{\mathrm{e}}$ & $\mathrm{kWh}_{t}^{c}$ & $\mathrm{kWh}$ & $\mathrm{kWh}$ & $\mathrm{kWh}_{\mathrm{t}}^{c}$ \\
\hline Transportation & 24,025 & 25 & 24,075 & 7,350 & 200 & 7,775 \\
\hline Commercial & 9,600 & 2,150 & 14,250 & 7,375 & 1,500 & 10,625 \\
\hline Residential & 13,500 & 2,300 & 18,450 & 11,125 & 1,400 & 150 \\
\hline Industry & 28,900 & 3,300 & 36,000 & 20,400 & 4,200 & 14,150 \\
\hline Feedstocks & 5,600 & -- & 5,600 & 2,500 & -- & 2,500 \\
\hline $\begin{array}{l}\text { Utility losses } \\
\text { (actua1) }\end{array}$ & 14,200 & -- & -- & 3,700 & -- & -- \\
\hline $\begin{array}{l}\text { Actual } \\
\text { consumption }\end{array}$ & 95,825 & 7,775 & 98,375 & 52,450 & 7,300 & 63,600 \\
\hline $\begin{array}{l}\text { Energy embodied } f \\
\text { in foreign trade }\end{array}$ & $1,800^{g}$ & - & 1,800 & $-4,600^{h}$ & - & $-4,600$ \\
\hline Net Consumption ${ }^{i}$ & 97,625 & 7,775 & 100,175 & 48,150 & 7,300 & 59,000 \\
\hline
\end{tabular}

$a_{U . S}$. data from Bureau of Mines (28), Cook (29) (see our Fig. 2 which excluded feedstocks), and Knecht and Bullard (30). We included 1,000 $\mathrm{kWh}$ per capita in wood wastes (SRI, ref. (30a)). Totals in $\mathrm{kWh}$ and $\mathrm{kWh}_{\mathrm{t}}$ columns do not agree because of difference in counting hydropower.

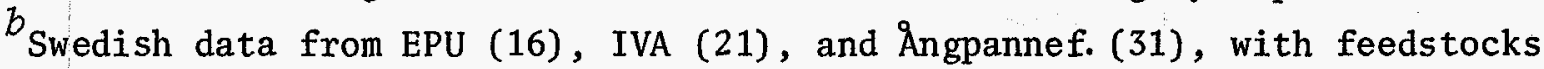
estimated from SOS (32) and EPK (33). Includes 4,000 kWh per capita wood wastes. Hydropower counted at $3,413 \mathrm{Btu} / \mathrm{kWh}_{\mathrm{e}}$ in $\mathrm{kWh}$ column.

$c_{k W h}$ calculated by distributing utility losses to end consumers. "Self" consumption in electrical sectors counted in "Industry". $\mathrm{kWh}_{t}$ column for U.S. includes hydropower at $10,460 \mathrm{Btu} / \mathrm{kWh} \mathrm{e}_{\mathrm{e}} ; \mathrm{kWh} \mathrm{t}$ column for Sweden counts all electricity at $10,400 \mathrm{Btu} / \mathrm{kWh}_{e}$. Actual "heat rate" for therma1 and back-pressure plants in Sweden has $8,870 \mathrm{Btu} / \mathrm{kWh}_{\mathrm{e}}$, including distribution losses, and $7,780 \mathrm{Btu} / \mathrm{kWh}$ for production only. Co-generated electricity in paper industry excluded from this column.

$d_{\text {Hydropower counted at } 3,413 \mathrm{Btu} / \mathrm{kWh}}$. Other losses according to actual consumption.

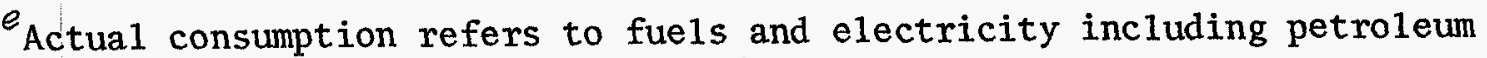
refining losses and other captive fuels.

$f_{\text {Embodied energy includes the process energy of refined fuels but not the }}$ energy available when the fuel is burned.

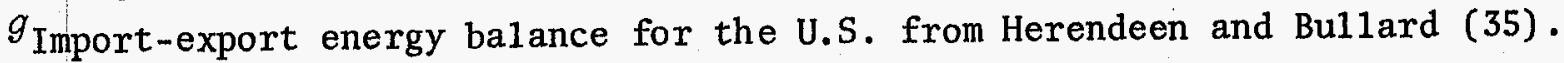

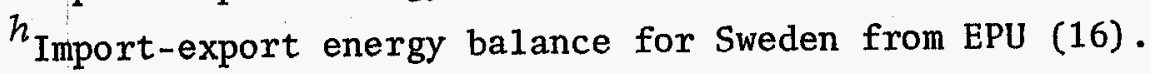

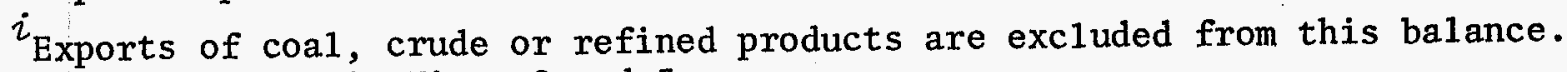
They are shown in Figs. 2 and 3. 
the amount of energy required to fulfill a given need (say, residential heating), thus affecting the $\mathrm{D}_{J}$ as well as the $\mathrm{E}_{J}$. These factors are also considered in the U.S. - Sweden energy comparison. The differences in $E_{J}$ 's between countries indicate possibilities for energy conservation via technical change, without requiring changes in lifestyle.

\section{A. Transportation}

In Table 3 we display basic passenger transportation data for Sweden and the United States. It can be seen immediately that major differences exist in a11 modes. In addition to the striking differences in automobile $\mathrm{D}^{-}, \mathrm{E}^{\prime}$, and $T$, we note that Swedish passenger transportation is more heavily concentrated in rail (including subway) and bus modes, at the expense of the auto and the airplane. Significantly, all Swedish $E_{J}^{\prime}$ 's are lower than the corresponding U.S. $E_{J}^{\prime} ' s$. This is due in part to higher load factors and the extensive use of air and bus charters.

In Table 4 we consider the automobile in more detail. We see that the Swedish $\mathrm{D}^{-}$is only $62 \%$ of the U.S. figure, and $E^{-}$, measured in $\mathrm{kWh} /$ pass-mi or gallons/pass-mi is only $60 \%$ of the U.S. figure. The biggest contributor to efficiency is the lower weight of Swedish autos, compared to American counterparts. The average weight of a car used in Sweden is $1100 \mathrm{~kg}$ (2420 1b), whereas for the United States the average weight is $1700 \mathrm{~kg}$ (3740 1b). The weight distributions are given in Fig. $4(43-45)$. Interpolating EPA measurements of fuel consumption versus inertial weight suggests that this difference alone reduces energy consumption per mile by $\sim 30 \%$ (43). The 1ack of power extras, automatic transmissions, and air conditioners reduces fuel demand further, as does the lower ratio of engine displacement to car weight of Swedish autos.

Beyond these technical differences in automobiles, however, are more subtle differences in auto utilization that have significant consequences. For trips of $10 \mathrm{~km}$ or less, in which auto fue 1 consumption is nearly double the average (47), the Swedes use private cars and public transit in the ratio $55 / 45$ (\% of trips) (45). In the U.S., by contrast, the ratio is 90/10 (FHWA, unpublished data). This traffic accounts for $65 \%$ of all auto trips in the U.S., resulting in lower average driving cycle efficiencies. Thus it becomes apparent why actual miles-per-gallon in Sweden are higher than predicted by the EPA (43): the driving cycle demands less energy. Surprisingly, load factors in both countries average approximately two. Probably the reason the Swedish value 
Tab1e 3. Passenger transportation tata for U.S. and Sweden. ${ }^{a}$

\begin{tabular}{|c|c|c|c|c|c|c|c|}
\hline \multirow{2}{*}{\multicolumn{2}{|c|}{$\begin{array}{l}\text { Passenger } \\
\text { Mode }\end{array}$}} & \multicolumn{3}{|c|}{ United States (1972) } & \multicolumn{3}{|c|}{ Sweden (1970) } \\
\hline & & $\begin{array}{c}\mathrm{D}_{\mathrm{J}}^{\prime} \\
\text { (pass-mi/ } \\
\text { capita) }\end{array}$ & $\begin{array}{c}E_{J}^{\prime} \\
(\mathrm{kWh} / \\
\text { pass } \\
\text { mi }) \\
\end{array}$ & $\begin{array}{c}\mathrm{T}_{\mathrm{J}} \\
\text { capita) }\end{array}$ & $\begin{array}{c}\mathrm{D}_{\mathrm{J}}^{\prime} \\
\text { (pass-mi/ } \\
\text { capita }\end{array}$ & $\begin{array}{c}E_{J}^{\prime} \\
\begin{array}{c}(\mathrm{kWh} / \text { pass } \\
\mathrm{mi})\end{array} \\
\end{array}$ & $\begin{array}{c}\mathrm{T}_{\mathrm{J}} \\
(\mathrm{kWh} / \\
\text { capita) } \\
\end{array}$ \\
\hline \multicolumn{8}{|l|}{ Auto ${ }^{C}$} \\
\hline$<30 \mathrm{mi}$ & & 4,850 & 1.72 & 8,330 & 1,825 & -- & -- \\
\hline$>30 \mathrm{mi}$ & & 4,200 & 1.02 & 4,300 & 3,225 & -- & -- \\
\hline $\begin{array}{l}\text { Total } \\
\text { Bus }^{d}\end{array}$ & $(1970$ & $\begin{array}{l}9,050 \\
7,900\end{array}$ & $\begin{array}{l}1.41 \\
1.41\end{array}$ & $\begin{array}{l}12,630 \\
11,200)\end{array}$ & 5,050 & .74 & 3,760 \\
\hline Local $<$ & $<30 \mathrm{mi}$ & 112 & .50 & 56 & 460 & .41 & 200 \\
\hline Interci & ity $>30 \mathrm{mi}$ & 122 & .30 & 42 & 251 & & \\
\hline \multicolumn{8}{|l|}{ Raile } \\
\hline Local & $<30 \mathrm{mi}$ & 64 & $.21(.63$ & 13.7 & 85 & $.16(.48)^{f}$ & 15 \\
\hline Interci & ity $>30 \mathrm{mi}$ & 21.3 & .87 & 18.6 & 356 & $.25(.75)^{f}$ & 90 \\
\hline Total Lo & and & 9,370 & 1.36 & 12,760 & 5,975 & .68 & 4,065 \\
\hline Air Dome & estic & 490 & 3 & 1,500 & $46\}$ & $1.12(?)$ & $275(?)$ \\
\hline Air Inte & ernationa ${ }^{g}$ & $243(?)$ & $1.38(?)$ & 335 & $200 \frac{1}{1}$ & & \\
\hline $\begin{array}{l}\text { Other } \mathrm{Pa} \\
\text { Military }\end{array}$ & $\begin{array}{l}\text { assenger, } \\
y\end{array}$ & -- & -- & 1,500 & -- & $?$ & 200 \\
\hline Total $\mathrm{Po}$ & assenger & 10,103 & -- & 16,095 & 6,221 & -- & 4,540 \\
\hline
\end{tabular}

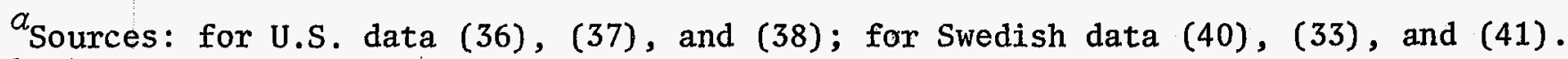

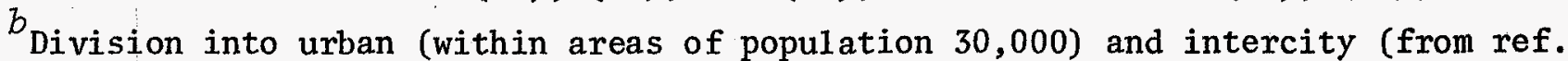
(41)) do not exactly correspond to our classification by local (30 miles) and intercity.

${ }^{c}$ Ref. (36) gives 1969 load factors that imply an overall load factor for automobiles of 1.7, which seems unreasonably low. Refs. (37) and (38) imply load factors of 2.2 , while ref. (42) assumes a load factor of 1.9 , which we adopt. There was a similar discrepancy in the Swedish data, most references giving an implied overall load factor of 2 , with one reference giving 1.7 . We adopt 2 , since the driving in Sweden is dominated by family driving to a greater degree than in the U.S. (The load factor is defined as the ratio of passenger miles to vehicle miles.)

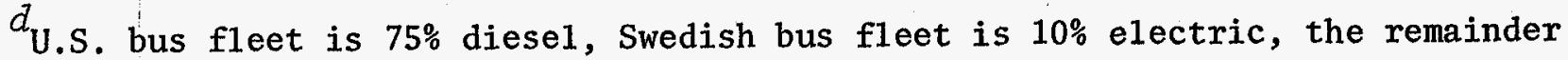
either diesel or gasoline.

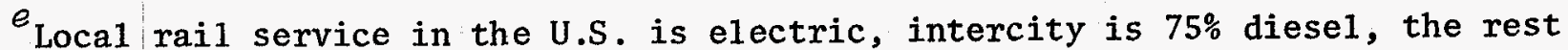
electric. In Sweden $90 \%$ of rail service is electric, the remainder diesel.

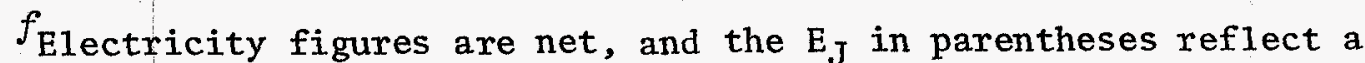
theoretical $3 \mathrm{kWh}_{\mathrm{t}} / \mathrm{kWh}_{\mathrm{e}}$.

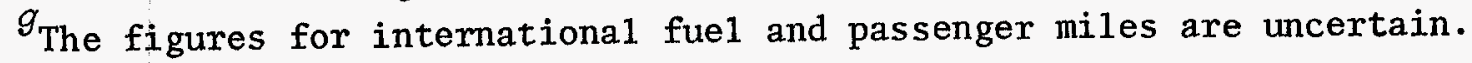


Table 4. Automobile data for the U.S. and Sweden (1970). (Conversions used: 1 U.S. gal $=33.75 \mathrm{kWh}$; $1 \mathrm{mi}=1.6 \mathrm{~km}$.)

\begin{tabular}{|c|c|c|c|c|}
\hline & U.S. & Refs. & Sweden & Refs. \\
\hline Persons/vehicle & 2.25 & $(42)$ & 3.4 & $(16)$ \\
\hline Licensed drivers/capita & 0.8 & (38) & 0.4 & $(16)$ \\
\hline Pass-mi/capita & 7,900 & $(42)$ & 5,050 & $(40)$ \\
\hline Vehicle mi/capita ${ }^{\alpha}$ & 4,160 & (37) & 2,560 & $(46)$ \\
\hline Mi/vehicle & 9,360 & (37) & 8,900 & $(37)$ \\
\hline Load factor & 1.9 & $(42)$ & 2.0 & $(40)$ \\
\hline Average weight $(\mathrm{kg})$ & 1,900 & (43) & 1,100 & $(44)$ \\
\hline $\begin{array}{l}\text { Miles per gallon } \\
\text { Actual }\end{array}$ & 13.7 & $(37,43)$ & 24 & $(43-45)$ \\
\hline Theoretical & 12.5 & & 20 & \\
\hline $\mathrm{kWh} /$ pass-mi & 1.4 & & 0.73 & \\
\hline kWh /capita & 11,200 & & 3,710 & \\
\hline
\end{tabular}

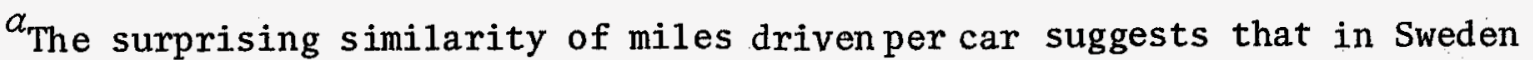
second cars are replaced by mass transit, and a significant number of families have no car at all.

$b_{\text {Theoretical miles-per-gallon is estimated from the weight-fuel economic }}$ statistics of the EPA. Actual is determined by dividing actual miles driven by fuel consumed. Swedish theoretical value ( $24 \mathrm{mpg}$ ) from U1lén (44) matches actual for Sweden. 


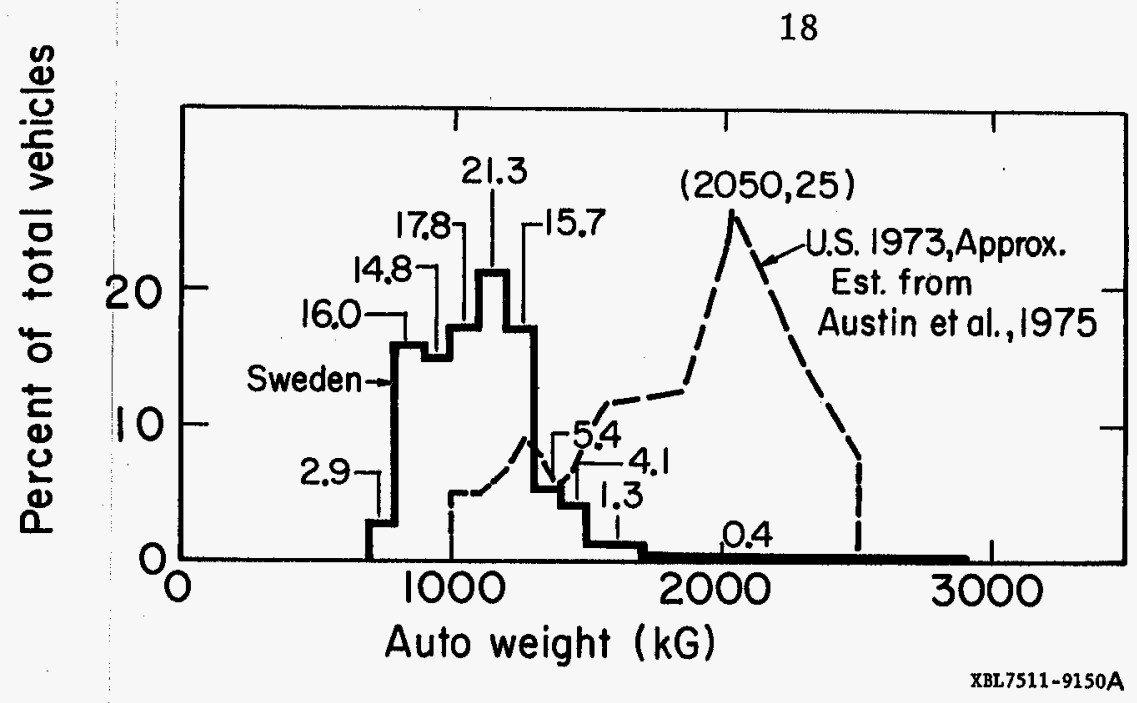

Fig. 4. Distribution of autos by weight, 1974 . From (44). Figures for U.S., 1973, estimated from (43).

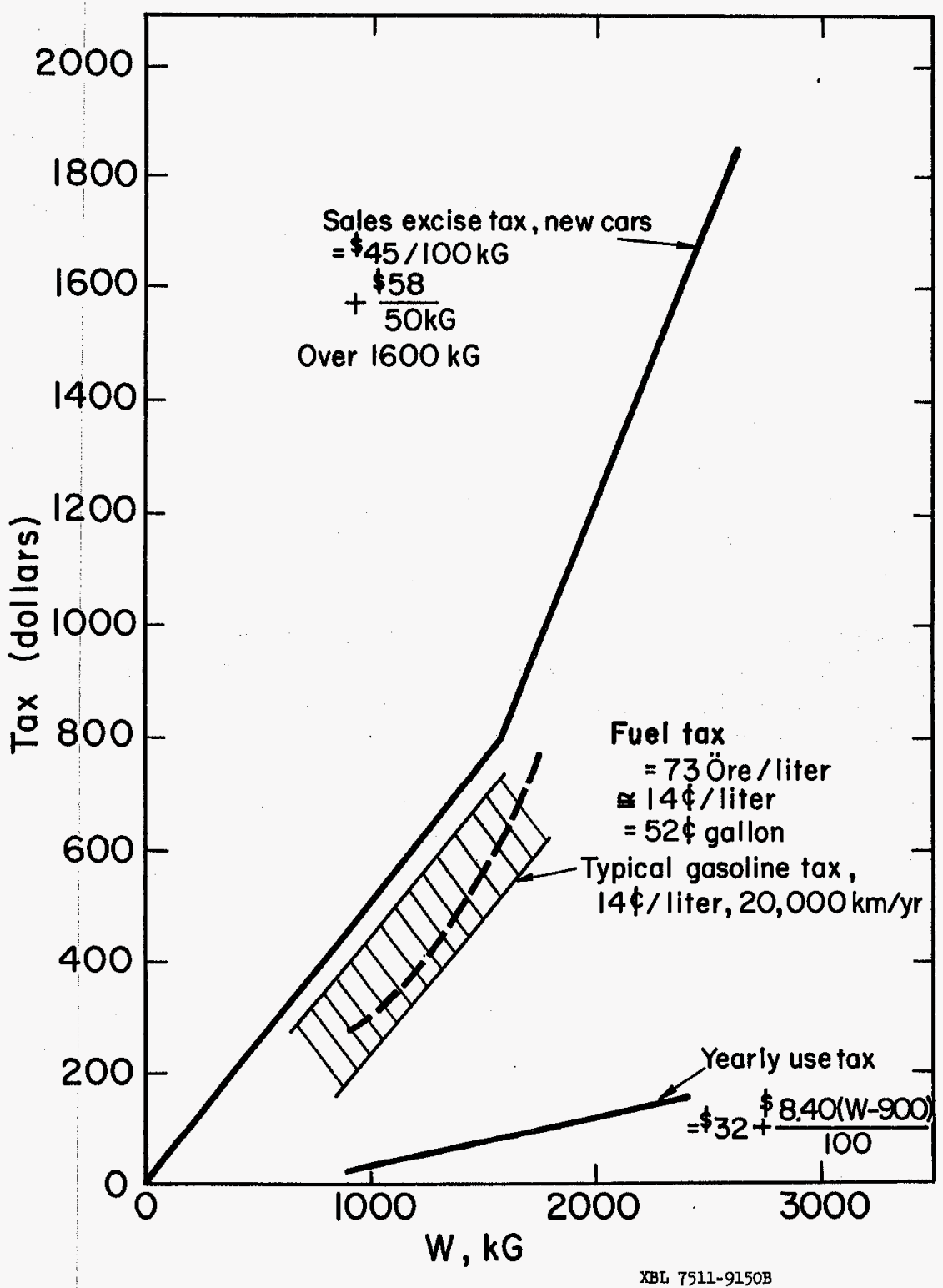

Fig. 5. Taxes on automobiles and gasoline in Sweden, 1974 (using the old exchange rate $5.18 \mathrm{skr} / \$$ ). Shaded area and dotted line give estimate of gasoline tax as a function of weight. From (23), (44), (48). 
is as low as in the U.S. is that the smaller families in Sweden compensate for that country's higher family use relative to commuter use.

A factor reducing Swedish automobile energy use further is that the speed limit was as high as $110 \mathrm{~km} / \mathrm{hr}(68 \mathrm{mph})$ on only about $10 \%$ of the largest highways, with a $90 \mathrm{~km} / \mathrm{hr}$ or lower (55 mph) limit on the remaining $90 \%$ of the main highways. This is in contrast to the U.S., where highway speed limits were commonly 65 mph (or greater) in 1971.

The availability and use of mass transportation in local and 1ong distance travel is an important factor in the optimization of the use of the auto discussed above $(25,26)$. In Stockholm, Gothenburg, and Ma1mö, representing more than 25\% of Sweden's population, mass transit, motor bikes and pedal bikes account for $75 \%$ of all commuting (41). The figure for the entire country is $46 \%$. Mass transit provides half of this, mostly in the above named cities. Most of the cities of over 50,000 people in Sweden have bus systems reinforced by important economic incentives, including subsidies, that encourage use by riders going into the city center. In Gothenburg, for example, one can obtain a round trip ticket for the price of a single fare by using the street cars and buses at off-peak daytime hours; in Stockholm and other cities a $50 \mathrm{skr}$ (now $70 \mathrm{skr}$ ) pass allows unlimited transportation on all rail and bus lines. Buses are often as close as four minutes apart during peak hours, and rapid rail and buses provide direct service to locales as much as $40 \mathrm{~km}$ from the city centers. Thus to the city or suburban dweller in Sweden, mass transit presents a viable and economic alternative to the use of an automobile, and development of suburbs and new towns around rail and bus stations reflects the popularity of mass transportation. For longer trips, alternatives to auto txansport in Sweden are a1so available. Inter-city buses, semi-charter buses, and trains carry $20 \%$ of the passenger miles in trips over $50 \mathrm{~km}$. Swedish Railways offers hourly departures between Ma1mö, Gothenburg, and Stockholm during day and early evening hours, traveling at average speeds of $80-100 \mathrm{~km} / \mathrm{hr}$.

We should not omit, however, discussion of some of the discentives that discourage use of automobile transit in Sweden. In Stockholm no 24-hour free street parking exists in the greater downtown area and parking fines begin at $\$ 12.50$. Both Stockholm and Gothenburg have set up systems of barriers, one way streets, mass transit-only lanes or passage ways, and pedestrian-only streets that further discourage the use of the auto. It has been noted $(25,26)$ that some of the gains made against the auto have been gradually eroded. Nevertheless, 
the auto's share of all passenger miles has stabilized at $82 \%$ in Sweden (33); the U.S. figure is $92 \%$ (38).

The tax system has contributed strongly to the control of the auto in Sweden. In 1971, the gasoline tax of $50 \$ /$ gallon raised the price by $250 \%$ to 70 /gallon $(23,48)$. Automobile excise taxes and yearly fees rise in proportion to vehicle weight with the formula shown in Fig. 5. These fuel and weight taxes influence owners to purchase light cars, as the lack of cars above $1600 \mathrm{~kg}$ (the U.S. average) shows (Fig. 4). In addition, the excise taxes raise the cost of a new car relative to the cost of maintenance, making it more worthwile in Sweden (vis a vis the U.S.) to keep an older car in running condition. The average car in Sweden has a 1ifetime of about 14 years compared to a U.S. 1ifetime of less than 10 years.

For freight transport, given in Table 5, the largest difference in per capita energy use is associated with distances through which goods are moved. A lesser, though still important, factor is the energy intensity of freight movement. Although a complete study of efficiency is yet to be made, some important factors can be identified. Among these we note that Swedish trucks are not prohibited from hauling freight on return trips. Also, small station wagons and four cylinder microbuses or diesel mini-trucks are used extensively for short hauls in Sweden, in contrast to the heavier pickup or panel trucks used in the U.S., thus more closely matching mode and vehicle to the demands of the task. Much of the difference in freight miles would be accounted for by shipments of Swedish exports of raw materials through other countries, exports that far outweigh (litera11y) imports. These are not counted in our study. A1so, coal and other fuels are transported over much greater distances in the U.S. than are fuels in Sweden.

Energy used in foreign passenger trave1, particularly in European countries where this constitutes a significant fraction of what corresponds to domestic travel in the U.S., may distort comparative energy use analysis. This is particularly true of air travel. Nearly every passenger flight connecting Sweden with anywhere stops in Copenhagen, where most of the fuel for the trip is put aboard. Thus Danish fuel intensity per air passenger mile is abnormally high (8), while that for Sweden is low (16). It is also difficult to credit passenger miles when foreign visitors travel to or within a country. Because of these uncertainties we have refrained from drawing conclusions from the great differences in $E^{-}$(air passenger travel) seen in Table 3. 
Table 5. Goods transportation data for the U.S, and Sweden. ${ }^{a}$

\begin{tabular}{|c|c|c|c|c|c|c|}
\hline & \multicolumn{3}{|c|}{ United States (1972) } & \multicolumn{3}{|c|}{ Sweden (1970) } \\
\hline & $\begin{array}{c}\mathrm{D}_{\mathrm{J}} \\
(\text { ton-mi/ } \\
\text { capita) }\end{array}$ & $\underset{\substack{\mathrm{J} \\
\text { ton-mi } /}}{\mathrm{E}_{\mathrm{kWh}}}$ & $\begin{array}{l}\mathrm{T}_{\mathrm{J}} \\
\text { (kWh/ } \\
\text { capita) }\end{array}$ & $\begin{array}{c}\mathrm{D}_{\mathrm{J}} \\
\text { (ton-mi/ } \\
\text { capita) }\end{array}$ & $\begin{array}{c}\mathrm{E}_{\mathrm{J}} \\
(\mathrm{kWh} / \\
\text { ton-mi })\end{array}$ & $\begin{array}{c}\mathrm{T}_{\mathrm{J}} \\
\text { (kWh/ } \\
\text { capita) }\end{array}$ \\
\hline \multicolumn{7}{|l|}{ Truck } \\
\hline Local $(0-30 \mathrm{mi})$ & 360 & 1.95 & 700 & 339 & 0.58 & 200 \\
\hline Intercity $(>30 \mathrm{mi})$ & 2069 & 0.63 & 1430 & 1284 & $\underline{0.86}$ & $\underline{1100}$ \\
\hline Total truck & 2429 & 0.88 & 2130 & 1623 & 0.8 & 1300 \\
\hline Rail & 4132 & 0.19 & 800 & 1350 & $0.6(.18)^{2}$ & b. 80 \\
\hline Domestic Air & 20 & 7.5 & 150 & -- & - & -- \\
\hline \multicolumn{7}{|l|}{ Water } \\
\hline Domestic & - & $\sim$ & 420 & 704 & 0.3 & 190 \\
\hline International & -- & -- & 480 & - & - & -- \\
\hline Total goods & 6585 & -- & 3980 & 3670 & -- & 3170 \\
\hline $\begin{array}{l}\text { Non-revenue goods } \\
\text { transport (agric.., } \\
\text { forestry, construc., } \\
\text { etc.) }\end{array}$ & -- & -- & 1850 & -- & -- & 470 \\
\hline Pipeline & - & - & $200^{c}$ & - & -- & -- \\
\hline other & - & -- & $120^{c}$ & - & - & 930 \\
\hline Totals & 6585 & -- & 6230 & -- & - & 4570 \\
\hline
\end{tabular}

Sources: U.S. data from Knecht and Bullard (30), FEA (39), and BNL (30b). Swedish data from (40), and EPU (16), with the breakdown for truck by distance based on the 1973 distribution.

$b_{\text {Figure in parentheses reflects } 3 \mathrm{kWh}} / \mathrm{kWh}_{\mathrm{e}}$ conversion factor.

1971 data. 
B. Residentia1 and Commercia1 Energy Use

A comparison of energy use in the residential and commercial sectors is given in Table 6. Although the per capita consumption is significantly lower in most categories, a full appreciation of the differences are only obtained by examining the $D_{J}^{\prime \prime} s$ and $E_{J}^{\prime}$ 's separately.

Space heating, consuming over one half of the total (Table 7), shows very large differences in efficiency, when account is taken of the differing climates and the actual energy use per square foot of residential or commercial space. The larger number of degree days in Sweden is compensated for by considerably lower heating intensity $\left(\mathrm{kWh} / \mathrm{deg}\right.$-day $\mathrm{m}^{2}$ ). A study of insulation in Swedish homes and apartments showed that U-values for heat loss have declined steadily to a typical value of $.06 \mathrm{Btu} / \mathrm{hr} \mathrm{ft}^{2}-{ }^{\circ} \mathrm{F}$ ). One can almost guess the year of construction of a residence in Sweden by the U-values, the scatter from the average value for any year of building being very low (16). This indicates that additional factors have acted, via stringent building codes, to permit only energy efficient (and economic) construction in housing (52). In contrast, U.S. U-values have been set mainly by a weak FHA minimum property standard, which before 1971 was $0.12 \mathrm{Btu} / \mathrm{hr}-\mathrm{ft}^{2}-{ }^{\circ} \mathrm{F}$ for ceilings and $0.19 \mathrm{Btu} / \mathrm{hr}-\mathrm{ft}{ }^{2}-{ }^{\circ} \mathrm{F}$ for walls (50). The U.S.-Swedish ratio of U-values of 2 is nearly equal to the average ratio of heating intensities. By implication, the Swedish houses also have correspondingly less infiltration and heat loss through glass, by use of storm windows and double glazing, to maintain the overa11 ratio (17).

A1 though the lower heat loss in Swedish houses is in part a response to the more severe climate, this is not the primary reason, as seen in Table 7 where we present the heating intensity in various regions in the U.S. and Sweden, so that intensity at a given number of degree-days can be compared. Although there is little overlap between the U.S. and Swedish degree-day values, the plots of intensity ( $\mathrm{kWh} / \mathrm{m}^{2}$-deg-day) versus degree-days clearly lie on different curves for Sweden and the U.S. The Swedish values are also nearly independent of degree days, reflecting the centralized standards, probably indicating that before the embargo the standards were sufficiently high that there was little economic incentive, even in the extreme north, to exceed these standards.

In Sweden the mix of single family dwellings (SFD) $42 \%$ and apartments (MFD) $58 \%$, is considerably different from that in the U.S. where in $197071 \%$ were SFD and $29 \%$ MFD. However, this difference does not account for much of 
Table 6. Per capita residential and commercial energy use in the U.S. and Sweden (1972).

\begin{tabular}{|c|c|c|}
\hline \multicolumn{3}{|l|}{ Direct fuel $(\mathrm{kWh})$} \\
\hline Heating & 9,660 & 8,200 \\
\hline Water heating & 1,950 & 3,300 \\
\hline Gas appliances & 630 & 1.25 \\
\hline Second homes & -- & 300 \\
\hline \multicolumn{3}{|l|}{ Electricity $(\mathrm{kWh})$} \\
\hline Refrigerator and stove & 610 & 530 \\
\hline Lighting & 335 & 105 \\
\hline Air conditioning & 300 & -- \\
\hline Other appliances & 590 & 475 \\
\hline Heating & 280 & \multirow{2}{*}{$400^{c}$} \\
\hline Water heating & 500 & \\
\hline District heating saving & -- & $1,300^{d}$ \\
\hline Total net use (kWh) & 14,855 & 12,135 \\
\hline Electric conversion loss at U.S. rate ${ }^{e}$ & 5,230 & 3,020 \\
\hline $\begin{array}{l}\text { Total gross use }\left(\mathrm{kWh}_{\mathrm{t}}\right) \\
\text { (with actual losses) }\end{array}$ & $\begin{array}{c}20,085 \\
(--)\end{array}$ & $\begin{array}{c}15,135 \\
(12,820)\end{array}$ \\
\hline \multicolumn{3}{|l|}{ Commercial: } \\
\hline Floor space $\left(\mathrm{m}^{2}\right)$ & 10 & $13^{f}$ \\
\hline \multicolumn{3}{|l|}{ Direct fue1 (kWh) } \\
\hline Space heat & 5,625 & 4,800 \\
\hline Water heat & 790 & -- \\
\hline Air Conditioning & 200 & -- \\
\hline \multicolumn{3}{|l|}{ Electricity $\left(\mathrm{kWh}_{\mathrm{e}}\right)$} \\
\hline Air Conditioning & 205 & -- \\
\hline Lighting & 1,250 & 625 \\
\hline Electric heat and other & 310 & 1,075 \\
\hline Total net use $(\mathrm{kWh})$ & 8,380 & 6,500 \\
\hline Electric conversion loss ${ }^{e}$ & 3,530 & 3,200 \\
\hline $\begin{array}{l}\text { Total gross use (kWh) } \\
\text { (with actual losses) }\end{array}$ & $\begin{array}{c}11,910 \\
(--)\end{array}$ & $\begin{array}{c}9,700 \\
(7,280)\end{array}$ \\
\hline
\end{tabular}


(Table 6 continued -- footnotes)

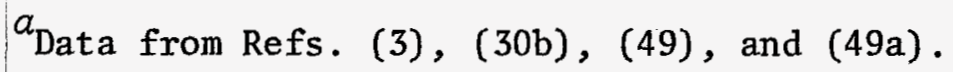

$b_{\text {Data taken from Refs. }}(16),(41),(53)$, and (54).

c Includes hot water in all-electric homes, and second homes.

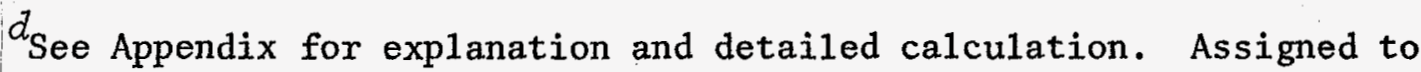
residential sector for convenience.

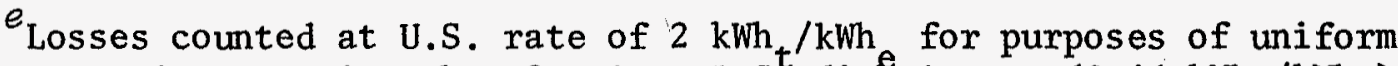
comparison, as in Table 2. Actual Swedish losses $\left(0.46 \mathrm{kWh}_{\mathrm{t}} / \mathrm{kWh}_{\mathrm{e}}\right)$ reflected in total column in parentheses.

$f_{\text {This value is obtained from the volume of commercial office space }}$ (Ref. (16)) by assuming a 4-meter room height. 
the increased heating efficiency, as the $\mathrm{kWh} / \mathrm{m}^{2}$ was only slightly lower in Swedish apartments than in single family dwellings, and the kWh/cap was also very similar, due to the higher number of people per house in SFD. In apartments common metering of all units in a building removed the incentive to conserve, raising both temperature and hot water use (41).

Electric heating in Sweden was increasing rapidly, as was U.S. growth, until the embargo of 1973 caused a re-evaluation of the overall effectiveness of such systems. In 1972, 7\% of Swedish homes (15\% of SFD) were heated electrically, similar to the $8 \%$ in the United States, but much less than the approximately $20 \%$ in Norway, where hydroelectricity is the largest single contributor to the total energy supply. Swedish all-electric homes have typical heat losses of two-thirds of the average of oil heated homes considered in Table 7 (17).

In the commercial sector, overall energy use per square meter of space may be as much as $30 \%$ lower in Sweden than in the U.S. (16), even before the difference in heating degree-days is considered. The heating intensity, when measured in $\mathrm{kWh} / \mathrm{m}^{2}$-deg-day is approximately 2.5 times lower than in the U.S. We attribute this mainly to the same differences in insulation, ventilation, and construction standards that applied to the residential sector, but further confirmation of the reasons for this difference should be made. The energy consumed in the commercial sector is reduced further by more realistic lighting standards, which also lowers the need for cooling. (Unlike many large buildings in the U.S., Swedish office buildings do not require air conditioning in winter to remove the heat produced by high lighting levels.)

In Table 6 the important residential and commercial uses of electricity are also compared. Higher U.S. energy use arises primarily from a combination of factors: significantly more use of larger appliances like dryers; 1arge "frost-free" refrigerators; excess 1ighting; and more small applicances $(53,54)$. Air conditioning is conspicuously absent from Swedish electricity use, but accounts in the United States for on $1 y 12 \%$ of electricity used in the residential and the commercial sectors, and only $3 \%$ of our total energy use.

Water heating, another major energy user, requires typica11y $6200 \mathrm{kWh}$ per household in apartments (central water.heating) and $10,500 \mathrm{kWh}$ per household for single family dwellings in Sweden, while the corresponding U.S. figures are $9,600 \mathrm{kWh}_{t}$ per apartment and $11,500 \mathrm{kWh}$ per single family dwelling. Much of the hot water in Sweden is prepared in centralized systems, eliminating some of the convection and radiation losses of American single unit water heaters. On the 
Table 7. Residential space energy consumption (fossil fuels only) and heating efficiencies by climatic regions for the U.S. and Sweden.

$$
\text { U, s, }{ }^{\mathbf{a}}
$$

$\frac{\text { Sweden }^{b}}{\text { MFD }^{e}}$

\section{Energy Consumption:}

Persons/housing unit

3.3

5.1

0.66

Persons/room

Ave. area $\left(\mathrm{m}^{2}\right)$

Degree days $\left(68^{\circ} \mathrm{F}\right)$

$\mathrm{kWh} /$ housing unit

$\mathrm{kWh} / \mathrm{m}^{2}$

$\mathrm{kWh} / \mathrm{deg}-\mathrm{day}$

$\mathrm{kWh} / \mathrm{m}^{2}$ deg-day

$\mathrm{kWh} /$ capita
115

5500

34,000

300

6.2

0.054

9150
2.1

3

3.2

4.5

0.66

70

110

9200

$\begin{array}{rr}16,350 & 28,750 \\ 235 & 260 \\ 1.77 & 3.10 \\ 0.027 & 0.028\end{array}$

8200

Heating Efficiency by Climatic Regions:

\begin{tabular}{|c|c|c|c|c|c|c|}
\hline & \multicolumn{3}{|c|}{ U.S.e } & \multicolumn{3}{|c|}{ Sweden ${ }^{f}$} \\
\hline & Calif. & Penn. & Minn. & Ma1mö & Stockholm & Norrbotten \\
\hline Degree-days $\left(68^{\circ} \mathrm{F}\right)$ & 1900 & 5500 & 8500 & 7700 & 9200 & 13,000 \\
\hline $\mathrm{kWh} / \mathrm{m}^{2}$ deg-day & 0.11 & 0.063 & 0.049 & 0.028 & 0.027 & 0.026 \\
\hline
\end{tabular}

a Sources: Refs. (14), (15), (24), and (51). Single family dwelling figures, except $\mathrm{kWh} /$ capita, which includes a11 dwellings.

$b_{\text {Sources: Refs. }}(16),(17)$, and (53).

Multiple Family Dwe11ing

$\mathrm{d}_{\text {Single Family Dwelling }}$

esources: Refs. (14) and (15).

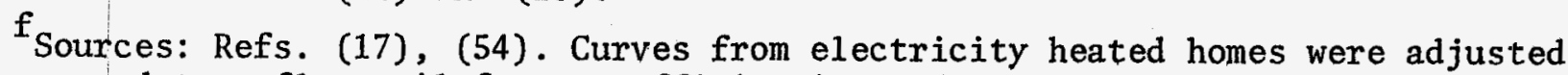
upward to reflect oil furnace efficiencies and construction. 
other hand, the larger systems are not easily metered individually; studies of energy use in apartments in Sweden $(16,41)$ noted that occupants paying individually for heat, hot water and electricity would use at least $15 \%$ less than those paying indirectly by sharing cost in the rent. Without detailed studies of water use, however, we cannot conclude anything about the $\mathrm{E}^{\prime}$.

An important mechanism for supplying space heat in Sweden is with district heating, in which central stations either produce heat alone, or co-generate heat and electricity. District heating supplies $19 \%$ of the total residential heat needs in Sweden (16). The energy balance for Swedish thermal power plants shows $24 \%$ of the $k$ Wh input appears as warm water or steam, primarily: for heating of homes and buildings, and 29\% of the output is electricity. Figure 6 illustrates the combined electricity-heat system of Malmö, a city of 250,000 (55). The overall effect of these systems, after the slightly lowered production of electricity is taken into account, is a net saving of fuel of $1300 \mathrm{kWh}$ per capita, which is $2 \%$ of the total energy consumption in Sweden (see Appendix for further detail).

\section{Industrial Energy Use}

In both Sweden and the United States the largest use of energy in industry is for basic materials processing. In Sweden this energy use is highly concentrated, five sectors accounting for $85 \%$ of the net use $(16,21)$.

In Table 8 we see that larger fractions of Sweden's manufacturing value added and energy use, compared to the U.S., are concentrated in the five energy intensive sectors. Additionally, the energy use in each sector and the value added is more concentrated toward materials processing - organic chemicals versus drugs, paper mills versus paper products, etc. Thus the mix of output in Swedish industry is more energy intensive than in the U.S. This is reflected in the $E$ for the five industries combined, which is higher in Sweden than in the U.S., although total $E$ for all of manufacturing in Sweden is very close to that in the U.S. While some energy intensive products, such as plastics, chemicals, and aluminum, are made in greater quantities in the U.S. than in Sweden, steel, cement, paper and pulp are made in greater amounts in Sweden. Much of Sweden's energy intensive raw output is exported.

However, these measures of intensity can be misleading. As Table 9 shows, the process energy intensities ( $E^{\prime}$ ) are signficantly lower in Sweden for virtually every product, usually because of reduced process heat requirements. These findings 


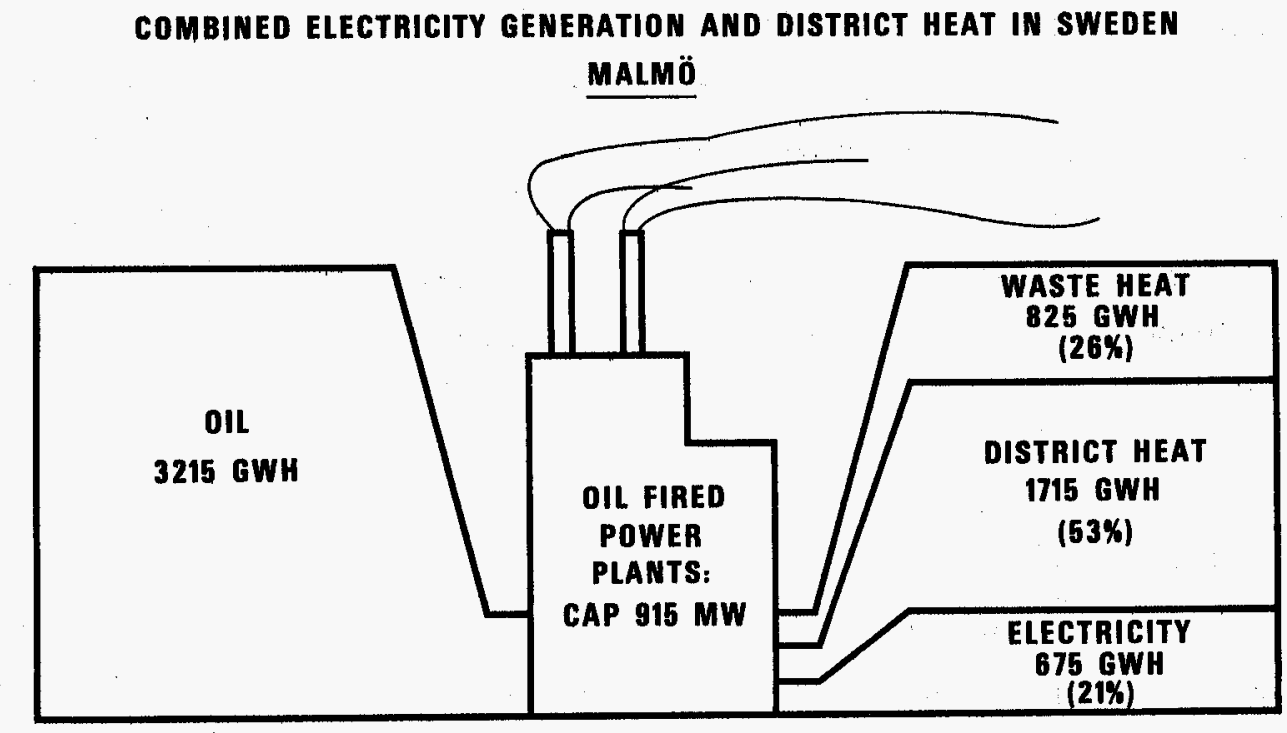

$1 \mathrm{GWH}=3.413 \times 10^{9} \mathrm{BTU} \approx 610 \mathrm{BBL}$

XBL7510-7770

Fig. 6. District heating and electricity co-generation in Malmo, 1973. From (55). 
suggest that Sweden's industry is more energy efficient than our own. More important, though, these findings stress the inaccuracy of measuring energy use, or efficiency, by aggregate ratios of energy use to value-added or GNP, as is done in Ref. (1). We note that similar differences in process energy intensities were found in the study of West Germany (11).

Swedish industries use more electricity as a fraction of all energy, or as a fraction of all electricity used in the whole economy, than American counterparts. This effect can be understood by noting that historically nearly all of Sweden's electricity was generated from hydropower, the predominant domestic energy resource; industries could be expected to utilize this resource, which has been less costly than steam electricity. In addition, the ratio of the price of electricity to the price of fuel (for the steel industry in particular) is lower in Sweden than in the U.S. These prices are summarized in Table 10.

The overal1 comparison of electricity used by industry is shown in Fig. 7 . Industrial electricity costs in Sweden are close to those in the U.S., but the dominance of several industries in Sweden that pay less than the U.S. average pul1s the average price in Sweden below that in the U.S. (Table 10). Since prices are so similar, we attribute the higher electric intensity (shift to the right in Fig. 7) to the lower ratio of the price of electricity to the price of fuels as compared to the U.S. (Table 10).

Additionally, however, other factors in Sweden tend to reduce specific industrial energy consumption compared to the United States. Sixty percent of a11 fuel used in the paper industry (which consumed $16 \%$ of a11 energy in Sweden) is provided internally by barks and liquors as opposed to $35 \%$ in the U.S. (21), but a third of the electricity used by that industry, and smaller fractions elsewhere, is co-generated with steam production $(16,64)$, thus reducing fuel needs. Some savings through co-generation have been obtained, for example, in Germany (11) and are considered to be economic for the U.S. (65), where half of the electricity consumed in the paper industry is self-generated, but only a small amount is co-generated.

In addition to energy savings in process industries in Sweden, assembly industries there tend to show lower use of fuel per unit of product (or value added) than in the U.S. This comes about in spite of more important space heating requirements compared to the U.S., in some cases surpassing electric drive and lights. A total of $20 \%$ of Sweden's industrial use is for space heating. In the entire Volvo concern, encompassing several large assemb1y plants, 1974 
Table 8. Energy use in industry-economic overview ${ }^{a}$

\begin{tabular}{|c|c|c|c|c|c|c|c|c|c|c|}
\hline \multirow{3}{*}{ Industry Sectors } & \multirow{3}{*}{ SIC } & \multirow{3}{*}{ SNI } & \multirow{3}{*}{\multicolumn{2}{|c|}{$\begin{array}{l}\mathrm{D}_{\mathrm{J}} \\
\text { Value added } \\
\frac{(\$ / \text { capita })}{\text { US Sweden }}\end{array}$}} & \multicolumn{2}{|c|}{$E_{J}(k W h / \$)^{b}$} & \multicolumn{4}{|c|}{$\mathrm{T}_{\mathrm{J}}^{\mathrm{b}}$} \\
\hline & & & & & \multirow[t]{2}{*}{$\begin{array}{l}\text { US } \\
(1971)\end{array}$} & \multirow[t]{2}{*}{$\begin{array}{l}\text { Sweden } \\
(1970)\end{array}$} & \multicolumn{2}{|c|}{$\begin{array}{c}\text { U.S. } \\
(1971) \\
\end{array}$} & \multicolumn{2}{|c|}{$\begin{array}{l}\text { Sweden } \\
(1970)\end{array}$} \\
\hline & & & & & & & $\mathrm{kWh}$ & $W_{\mathrm{e}}$ & kWh & $\overline{k W h} \mathrm{e}$ \\
\hline \multicolumn{11}{|l|}{ MANUFACTURING } \\
\hline Paper $^{C}$ & 26 & 341 & 62 & 112 & 44 & 75 & 3200 & 290 & 7625 & 1300 \\
\hline $\begin{array}{l}\text { Market pulp } \\
\text { Paper mi11s } \mathrm{d} \\
\% \text { of sector }\end{array}$ & $\begin{array}{c}261 \\
262,3,-6\end{array}$ & $\begin{array}{l}34111 \\
34112,-113\end{array}$ & $\begin{array}{r}2 \\
24 \\
40 \%\end{array}$ & $\begin{array}{r}34 \\
60 \\
84 \%\end{array}$ & & & $\begin{array}{r}125 \\
2500 \\
82 \%\end{array}$ & $\begin{array}{r}25 \\
230 \\
88 \%\end{array}$ & $\begin{array}{r}3680 \\
3895 \\
99 \%\end{array}$ & $\begin{array}{r}500 \\
800 \\
100 \%\end{array}$ \\
\hline Chemicals & 28 & 351,352 & 156 & 84 & 25 & 34 & 3930 & 575 & 1135 & 540 \\
\hline $\begin{array}{l}\text { Organic } \\
\text { Inorganic }\end{array}$ & $\begin{array}{l}2815,-18 \\
2812,-13, \\
-16,-19\end{array}$ & $\begin{array}{l}35111 \\
35112\end{array} \mid$ & 16 & $\begin{array}{l}7 \\
9\end{array}$ & & & $\begin{array}{l}1575 \\
1220\end{array}$ & $\begin{array}{l}110 \\
250\end{array}$ & $\begin{array}{r}80 \\
110\end{array}$ & $\begin{array}{l}250 \\
100\end{array}$ \\
\hline $\begin{array}{l}\text { Plastics, fibers } \\
\text { Agricultural } \\
\% \text { of sector }\end{array}$ & $\begin{array}{l}-16,-1 \\
282 \\
287\end{array}$ & $\begin{array}{l}3513 \\
3512\end{array}$ & $\begin{array}{r}24 \\
8 \\
31 \%\end{array}$ & $\begin{array}{r}18 \\
7 \\
49 \%\end{array}$ & & & $\begin{array}{l}630 \\
115 \\
90 \%\end{array}$ & $\begin{array}{r}80 \\
15 \\
79 \%\end{array}$ & $\begin{array}{l}305 \\
120 \\
54 \%\end{array}$ & $\begin{array}{r}80 \\
55 \\
90 \%\end{array}$ \\
\hline $\begin{array}{l}\text { Feed stocks } \\
\text { consumed }\end{array}$ & \multicolumn{2}{|c|}{$\begin{array}{l}\text { Excluded from } \\
\text { totals }\end{array}$} & & & & & \multicolumn{2}{|c|}{4600} & \multicolumn{2}{|c|}{1500} \\
\hline Petroleum & 29 & $353,-4$ & 30 & 11.5 & 142.9 & 134 & 4000 & 145 & 1540 & 30 \\
\hline Refining ${ }^{f}$ & 291 & 353 & 25 & 8 & $152: 0$ & 187.5 & 3800 & 135 & 1500 & 23 \\
\hline$\frac{\text { Stone, Glass, }}{\text { Clay }}$ & 32 & 36 & 51 & 50 & $36: 3$ & 32.5 & 1850 & 120 & 1625 & 150 \\
\hline Primary metals & 33 & 37 & 110 & 103 & 51.8 & 37.7 & 5700 & 710 & 3880 & 910 \\
\hline $\begin{array}{l}\text { Basic steel } \\
\text { Alloys } \\
\text { Nonferrous } \\
\% \text { of sector }\end{array}$ & $\begin{array}{r}3312 \\
3313 \\
333\end{array}$ & $\begin{array}{l}37101 \\
37102 \\
37201\end{array}$ & $\begin{array}{r}46 \\
10 \\
8 \\
57 \%\end{array}$ & $\begin{array}{r}74 \\
3 \\
6 \\
81 \%\end{array}$ & & & $\begin{array}{r}4390 \\
80 \\
640 \\
90 \%\end{array}$ & $\begin{array}{r}190 \\
35 \\
300 \\
74 \%\end{array}$ & $\begin{array}{r}3065 \\
280 \\
370 \\
96 \%\end{array}$ & $\begin{array}{l}500 \\
160 \\
225 \\
97 \%\end{array}$ \\
\hline Total Energy Int & tensive $^{\mathrm{g}}$ & & 421 & 328 & 44.4 & 48.2 & 18,680 & 1700 & 15,800 & 3000 \\
\hline Other Manufactur & ring & & 1320 & 808 & 3.4 & 2.0 & 4525 & 1050 & 1600 & 710 \\
\hline Total Manufactur & ing & & 1741 & 137 & 13.3 & 15.3 & 23,205 & 2750 & 18,100 & 3710 \\
\hline $\begin{array}{l}\text { ENERGY HARVEST } \\
\text { (excluding refini }\end{array}$ & ing, elect. & tilities) & & & & & & & 500 & 280 \\
\hline MINING & & & & & & & 570 & 100 & 570 & 180 \\
\hline AGRICULTURE, FORES & STRY & & & & & & 1825 & 55 & 510 & 200 \\
\hline $\begin{array}{l}\text { CONSTRUCTION } \\
\text { (excluding vehicl }\end{array}$ & es) & & & & & & 900 & 16 & 650 & 85 \\
\hline $\begin{array}{l}\text { Total Industry ( } \\
\text { feedstocks) }\end{array}$ & (excluding & & & & & & $\overline{29,020}$ & $\overline{3.300}$ & 19,630 & 4460 \\
\hline
\end{tabular}


Footnotes for Table 8 ,

\footnotetext{
a Sources: for U.S. Refs. (30), (56), and (57); for Sweden Refs, (16), (33), and (35). $\mathrm{kWh}$ included in $\mathrm{kWh}$ figures,

$\mathrm{b}_{\mathrm{Net}}$. For gross $\left(\mathrm{kwh}_{\mathrm{f}}\right)$ multiply by $[(2 \mathrm{kWh} / \mathrm{kWh})+1]$, where the $\mathrm{kWh}$ and $\mathrm{kWh}$ are from $\mathrm{T}_{\mathrm{J}}$. $\mathrm{kWh}$ is included in the ${ }^{e} \mathrm{kWh}$ figure. U.S. Figures for $\mathrm{kWh}$ include self-generation but these are not included in the $E_{J}$. U.S. $E_{J}$ is for 1971; value added from (56) inflated to 1971 values.

${ }^{c}$ Includes wood wastes.

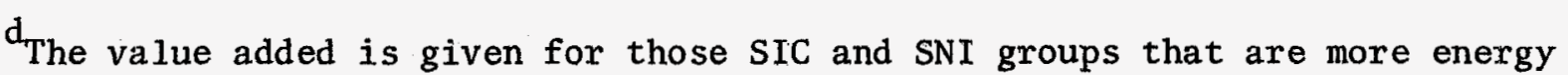
intensive than the average. Percent of sector gives the percent of the sector contained therein. It can be seen that Sweden's value added is more concentrated in these sectors,

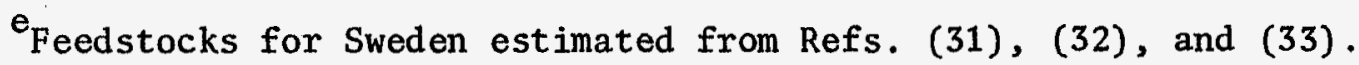

${ }^{f}$ Includes captive consumption not counted by most Swedish studies, but found in Refs. (31) and (32). Feedstocks subtracted from refining losses in Ref. (31). $500 \mathrm{kWh} /$ capita of non-fuel petroleum (lubricants, etc.) omitted but counted in Table 2. The Swedish refining $T$ could be as low as 1000 .

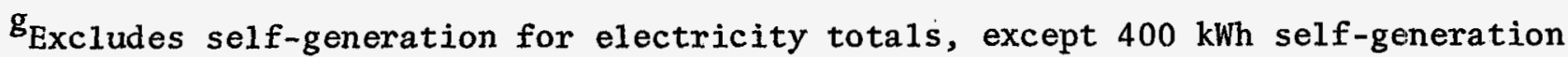
in paper and pulp industries in Sweden.
} 
Table 9. Materials and energy consumption data for the U.S. and Sweden. ${ }^{\mathbf{a}}$




Table 10, Energy intensities and costs in industry, ${ }^{a}$

\begin{tabular}{|c|c|c|c|c|c|c|c|}
\hline & \multicolumn{2}{|c|}{$\mathrm{T}_{J}(\mathrm{kWh} /$ capita $)$} & \multicolumn{2}{|c|}{$\mathrm{E}(\mathrm{kWh} / \$)$} & \multicolumn{2}{|c|}{$P(\phi / k W h)$} & \multirow{2}{*}{$\frac{\mathrm{P}_{\mathrm{e}} / \mathrm{P}_{f}}{\text { U.S. Sweden }}$} \\
\hline & $\begin{array}{l}\mathrm{U}, \mathrm{S} \\
(1971)\end{array}$ & $\begin{array}{l}\text { Sweden } \\
(1970)\end{array}$ & $\begin{array}{l}\text { U.S. } \\
\text { (1971) }\end{array}$ & $\begin{array}{l}\text { Sweden } \\
(1970)\end{array}$ & $\begin{array}{l}\text { U.S } \\
(1971)\end{array}$ & $\begin{array}{l}\text { yeden } \\
970)\end{array}$ & \\
\hline \multicolumn{8}{|l|}{$\begin{array}{l}\text { Five energy industries } \\
\quad(\text { excluding feedstocks) }\end{array}$} \\
\hline $\begin{array}{l}\text { Fuel }(f) \\
\text { Electricity }\end{array}$ & $\begin{array}{r}17,000 \\
1700\end{array}$ & $\begin{array}{r}12,800 \\
3000\end{array}$ & $\begin{array}{r}40 \\
4\end{array}$ & $\begin{array}{r}39.1 \\
9.2\end{array}$ & $\begin{array}{l}0.15 \\
0.81\end{array}$ & $\begin{array}{l}0.20 \\
0.75\end{array}$ & $5.4 \quad 3.5$ \\
\hline \multicolumn{8}{|l|}{ Other manufacturing ${ }^{c}$} \\
\hline $\begin{array}{l}\text { Fuel (f) } \\
\text { Electricity (e) }\end{array}$ & $\begin{array}{l}3500 \\
1075\end{array}$ & $\begin{array}{l}900 \\
700\end{array}$ & $\begin{array}{l}2.7 \\
0.8\end{array}$ & $\begin{array}{l}1.1 \\
0.9\end{array}$ & $\begin{array}{l}0.19 \\
1.2\end{array}$ & $\begin{array}{l}0.36 \\
1.1\end{array}$ & $6.3 \quad 3.1$ \\
\hline \multicolumn{8}{|l|}{ Tota1 manufacturing } \\
\hline $\begin{array}{l}\text { Fuel (f) } \\
\text { Electricity (e) }\end{array}$ & $\begin{array}{r}20,500 \\
2775\end{array}$ & $\begin{array}{r}13,700 \\
3700\end{array}$ & $\begin{array}{r}12.0 \\
1.6\end{array}$ & $\begin{array}{r}12.0 \\
3.3\end{array}$ & $\begin{array}{l}0.16 \\
1.0\end{array}$ & $\begin{array}{l}0.22 \\
0.82\end{array}$ & $6.0 \quad 3.7$ \\
\hline \multicolumn{8}{|c|}{ 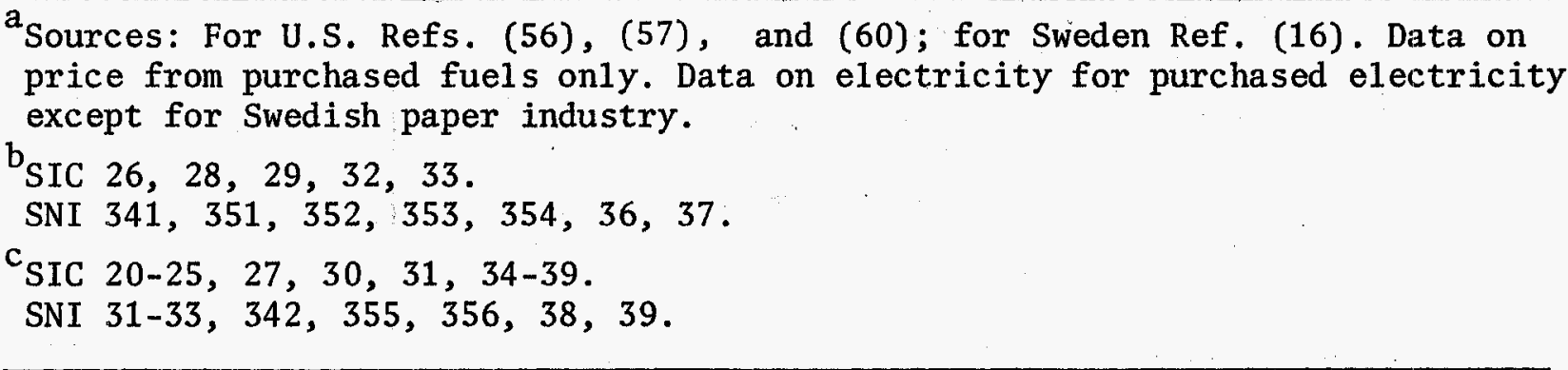 } \\
\hline
\end{tabular}




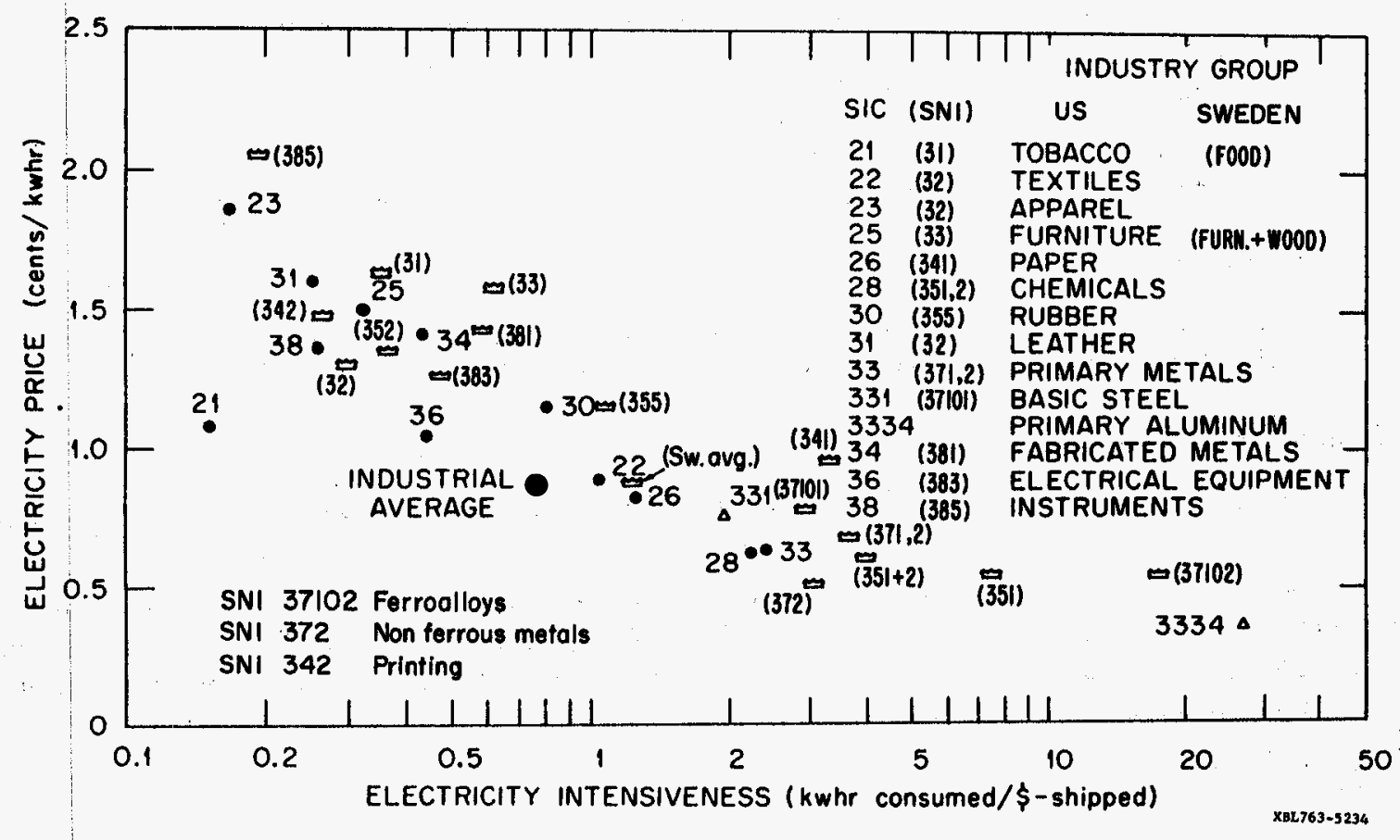

Fig. 7. Electricity intensiveness, $\$ / \$$ shipped, and price. U.S. data from 1967 Census of Manufacturers, assembled by Hirst (58a) shown as dots, triangles; Swedish data (from EPU (16)) shown as crowns. Use includes purchased only. SIC and SNI codes given for identification of similiar industries. 
energy use was estimated at $0.6 \times 10^{9} \mathrm{kWh}$ for space heat and hot water, a similar amount for process heat, and an equal amount for electricity, of which one third went for lighting and office use. (Volvo was able to cut its total energy use $25 \%$ after the oil embargo through "leak plugging") (61). If Swedish industrial fuel use were adjusted for comparison purposes to take into account the difference in climate, usage could be $10 \%$ lower.

The relatively more modern equipment in Swedish industry - Sweden's national accounts have grown significantly faster than those of the U.S. as the Swedish GNP approached ours - certainly contributes to the higher efficiency in Sweden, just as the U.S. industry improved energy efficiency through technological change since World War II in spite of falling energy prices (56) "Data collected by Meyers et al (56), compared with Swedish data ( $\mathrm{kWh} /$ ton or $\mathrm{kWh} / \$$ ), suggests that Swedish manufacturing energy intensity today 1ies on Meyers' projected U.S. curves $10-15$ years hence. Missing from Swedish industrial energy use was (and is) "interrruptible" gas at bargain prices, and cheap coal, two fuels that have been important to many U.S. industries and whose low price and availability fostered higher energy use in the past.

Both official Swedish government forecasts (16) and the views of individuals in industry $(61-63)$ reflect the belief that optimization to ever-increasing fuel prices will further reduce specific energy requirements of Swedish industry toward the end of the century, as many have also predicted for the United States (56). Since Sweden traditionally has paid a high industrial wage, the saving of energy has come about not by direct substitution of labor for energy, but through the substitution of energy management (61) and capital (B. Carlson in Ref. (16)) for energy.

Other factors in resource use in Sweden contribute to both lower demand per product and lower demand for energy intensive products themselves. It was noted above that Swedish autos outlast American counterparts, weigh less, and use materials that themselves require less energy than their American counterparts. Furthermore, Swedish consumers have maintained the widespread use of returnable bottles. Other utilization patterns (relative sizes of $D_{J}$ ) are interesting; in the late 1960 's plastic bags became popular, on1y to be replaced by paper again as the cost of plastic, made from imported petroleum, rose relative to the cost of paper made largely from domestic sources. We can generally conclude that cultural and institutional factors combine with economic and technical factors to effect energy savings in the industrial sector in Sweden relative to the United 
IMPORT-EXPORT BALANCE, 1973

(KWh per capita)

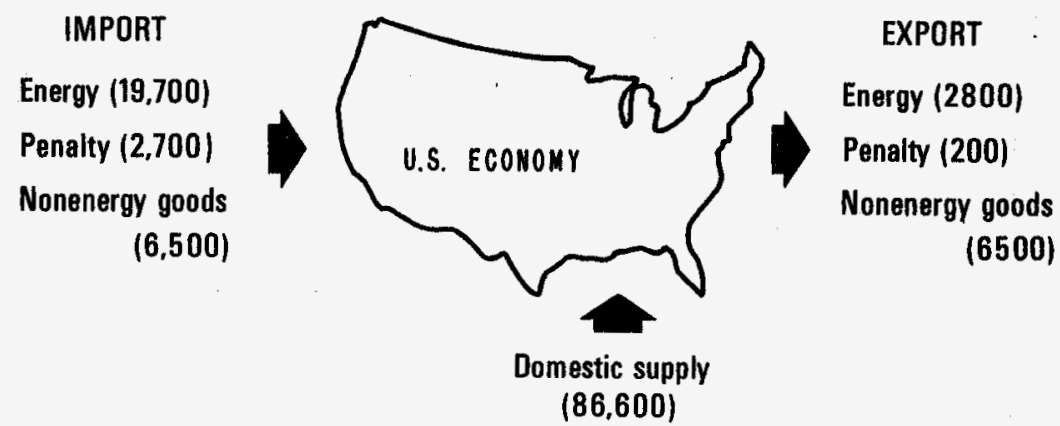

XBL763-5271

Fig. 8. Imports and exports of energy via foreign trade, U.S., 1973. "Penalty" refers to process energy embodied in refined fuels. From (35). For 1971, "penalty" in import side scales with imports of refined oil.

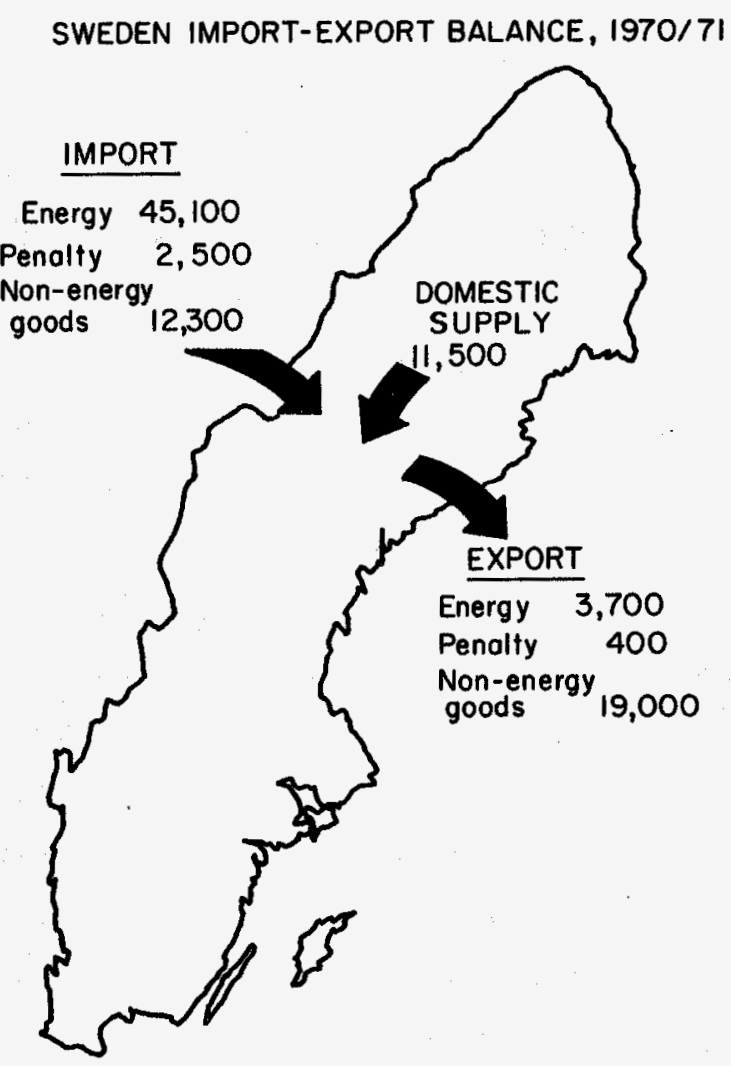

Fig. 9. Imports and exports of energy via foreign trade, Sweden, 1970. Includes wood wastes, but not the energy content of wood or paper as a fuel. From EPU (16). 
United States. This is mainly done by increasing efficiency (lowering the $E_{j}{ }^{\prime} s$ ), but changing the mix of products (mix of $D_{J}{ }^{\prime} s$ ) actually consumed in Sweden toward lower energy intensity is also significant in some areas. In future work we hope to analyze these differences in greater detail.

\section{Imports and Exports of Goods}

Since imports and exports comprise an important part of economic activity it is important to evaluate the energy embodied in non-energy trade, as well as the process energy embodied in refined fuels, such as gasoline. For the U. S., Herendeen and Bullard (35) found that while non-energy imports and exports contained equal amounts of energy, ${ }^{\ddagger}$ the imports of refined oil embodied more energy than exports of coal and refined oil products (excluding the energy actually in these fuels). The balance for 1973, indicated earlier in Table 2 and Fig. 2, is shown in Fig. 8. A similar balance for Sweden, evaluated by EPU (16) was shown in Table 2 and Fig. 3. The complete trade is shown in Fig. 9. It can be seen that the energy embodied in foreign trade affects Sweden - with an export surplus of embodied energy - far more than the U. S., with a small import surplus. An even greater affect was estimated for Denmark by E1baek (8) who found that the energy balance of trade amounted to an import of $20 \%$ of the energy consumed in Denmark. By contrast, West Germany has a large export surplus (11). Note that in every case the imports of fuets are much larger than any of these figures. We conclude that an accounting of the energy embodied in foreign trade widens the difference in energy use between Sweden and the U.S.

\section{ANALYSIS OF ENERGY DIFFERENCES AND CONCLUSIONS}

In Table 11 we show explicitly some important energy prices for Sweden and the U.S. The largest price differences occur in road fuels, even before considering the higher taxes on automobiles in Sweden. Electricity, on the other hand, has been relatively inexpensive (compared to fue1) in Sweden, due to the fact that in the past a large share of electricity has been hydropower (66). In 1971, electricity use in Sweden (7400 kWh per capita) was close

FCounting "direct" energy (applied by the producer of a good or service) and "indirect" energy (the energy required to produce the materials and services used by the producer, and so on). 
Table 11. Typical energy prices in the U.S. and Sweden. Exchange rate used is $\$ 1=5.18 \mathrm{skr}(1960-1970)$ and $4.30 \mathrm{skr}$ (1974).

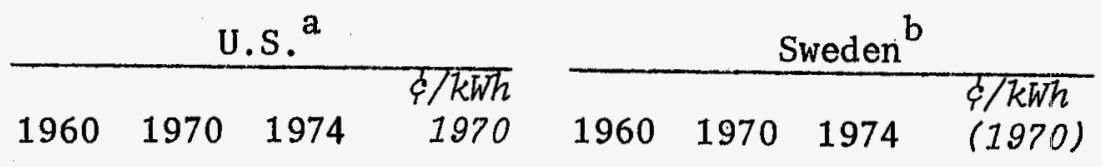

Oil Products $(\phi / g a 1)$ :

$\begin{array}{lcrrrrrrr}\text { Gasoline } & 30 & 35 & 45 & 1.04 & 53 & 61 & 116 & 1.82 \\ \begin{array}{l}\text { Diesel } \\ \text { Heating oil- }\end{array} & 23 & 28 & 35 & 0.83 & 42 & 48.8 & 90 & 1.45 \\ \quad \text { Sma11 customers } & 15 & 18 & 35 & 0.50 & & & & \\ \quad \text { Large customers } & 10.5 & 12 & 25 & 0.33 & 13.3 & 13.2 & 40.6 & 0.37 \\ \text { Heavy oil } & 7 & 8 & 23 & 0.23 & 7 & 8.5 & 22.5 & 0.24\end{array}$

Gas ( $\$ / M M B t u):$

Residential

Industrial

Firm service

Interruptable service

$\begin{array}{lllllll}120 & 130 & 190 & 0.43 & - & 550 \quad 680^{1973} & 1.9\end{array}$

$\begin{array}{ll}75 & 80 \\ 40 & 50-0.27-0.17=-\end{array}$

Coa1, Industrial

$(\$ /$ ton $):$

$\begin{array}{lllll}10 & 15 & 25 & 0.17 \quad-\quad 18\end{array}$

0.2

Electricity $(\phi / \mathrm{kWh})$ :

\begin{tabular}{|c|c|c|c|c|c|c|c|}
\hline Base & 2.75 & 2.75 & - & 2.75 & 3.14 & 2.12 & 2.3 \\
\hline $\begin{array}{l}\text { Base and space } \\
\text { heating }\end{array}$ & 1.75 & 2.0 & - & 1.5 & - & $\sim 1.5$ & $\begin{array}{l}1975 \\
2.0\end{array}$ \\
\hline Industrial & 1 & 1 & 1.5 & $(0.4-2.1)$ & - & 0.93 & $\begin{array}{l}19 \% 5 \\
1.8\end{array}$ \\
\hline
\end{tabular}

a Sources: Refs. (15), (24) and (57). Ref. (58) gives following prices ( $(/ k W h)$

for U.S. industry as a whole in 1971: gas 0.13 , coal 0.12 , oil 0.23 , electricity 0.98 , other 0.25 . Cf. Swedish prices.

b Sources: Refs. (16), (23), (48), and Swedish Embassy press release, 1975.

${ }^{c}$ Swedish gasoline taxes: $42 \$ /$ gal in 1970 , about $68 \$ / g a 1$ in 1974 . U.S. price includes $10-13 \$ /$ gal tax.

$\mathrm{d}_{\text {Coa1 }}$ price excludes captive and utility coal.

'Swedish figures based on $1700 \mathrm{kWh} / \mathrm{yr}(1960), 3000 \mathrm{kWh} / \mathrm{yr}(1970), 2000 \mathrm{kWh} / \mathrm{yr}$ (1974). 
to that in the U. S. (7700 KWh per capita), but more of this total was used in the industrial sector in Sweden and more in the residential/commercial sector in the United States. Other fuels in Sweden lie between these two extremes, being slightly more expensive in Sweden (before 1973) and used more efficiently there as well. Since the price of oil used for home heating in Sweden was comparable to U.S. values (until 1973), the length of the heating season, as well as institutional factors mentioned above, must account for the efficient use of that fuel for space comfort. Significantly, however, Sweden had no natural gas or domestic coal, two fuels whose low prices certainly encouraged intensive use in the U. S.

Higher energy prices alone, however, do not account for the more efficient energy use in Sweden. In our report and elsewhere, it has been stressed that while a given set of energy prices determines a mix of energy and other economic factors that allow production for the least cost, institutional and social factors determine how close individual consumers, firms and society as a whole come to this most economic energy use. In the United States, for example, mortgage policies and market considerations constrain developers to minimize first costs, rather than life cycle costs, constraints which do not appear to be applicable to construction in Sweden. We have also seen that building codes have imposed energy conserving construction more uniformly in Sweden. Additionally, the Swedish government has given priority to energy conservation in housing loans. Passenger transport in Sweden has also been strongly influenced toward energy conservation through government policy, in this case mainly through the market mechanism by various taxes and incentives. These factors also encourage important synergistic effects. Good intercity transport, and high costs of operating an automobile, tend to keep the population more concentrated. In addition to maintaining the viability of the public transport system itself, this situation also affects housing and living patterns in energy saving ways. With increased population densities apartment living is more common, allowing potential energy savings through fewer external walls, better insulation and more efficient heating systems. Shopping a1so becomes easier, with more neighborhood stores; trips are shorter, often on foot, and sma11er storage facilities are required, resulting in smaller capacity refrigerators with consequent electricity savings.

In a recent study of energy use in the U. S., Hannon (67) suggested that lowering the energy requirement for an economy by changing lifestyle and the 
$\operatorname{mix}$ of consumer goods (the $D_{J}$ ) would be difficult, because consumer expenditures would generate energy requirements no matter how they were directed. We have shown here that in Sweden the $D_{J}$ are shifted toward less energy intensive activities, and the $\mathrm{E}_{\mathrm{J}}$ toward higher efficiency. For both effects, dollars saved by saving energy in one activity and re-spent on another, do not, on the average, generate as much energy use as expenditures for a more energy intensive mix of $D_{J}$, or activities with less efficient $E_{J}$, would have done. All energy intensities are reduced through higher efficiencies, i.e., conservation, and shifts from high to low energy intensive activities are made at the same dollar level. Sweden, like other European countries, developed these energy economies to off-set its higher energy prices and balance of payments problem resulting from importing energy. This resulted in a higher standard of living for a given level of energy consumption. This suggests the answer to the dilemma posed by Hannon: in the face of energy scarcity and consequent rising energy prices consumers in the U. S. would seek to maintain their standard of living by optimizing energy use both through increased energy efficiency and through shifting to lower energy intensity activity.

In future work we hope to explore further both the underlying causes of and the mechanisms for achieving higher energy in Sweden. At this time, however, we offer some tentative conclusions about energy use obtained from the U. S. Sweden comparison:

1) For a given level of GNP, efficiency of energy use, climate and the $\operatorname{mix}$ of goods and services share in determining the energy requirements of an economy. Efficiency may be the most important factor in the long run and is affected predominantly by energy prices, though institutional and cultural factors play a role in how well energy use responds to energy costs.

2) Projecting energy needs on the basis of past correlations between energy and GNP (or other macro-economic variables) is a very insecure procedure, given both the spread in energy use in countries with a given. GNP and the great differences in efficiency, both actual and theoretical, with which individuals and firms use energy to carry out tasks. Conclusions commonly reached about the energy/GNP ratio (1), especially those that purport to show that the U. S. uses energy efficiently (solely on the basis of gross energy use, electricity use, and GNP $(68))$, are misleading and contradicted by in-depth studies such as our own. 
3) No matter how one counts hydropower, it does not account for a major portion of the difference between $U, S$, and Swedish energy consumption.

4) Adjustments of energy use in the U.S. and Sweden that reflect climate and the energy embodied in foreign trade increase the difference in energy consumption between Sweden and the U,S.

Our international comparison suggests that many energy conservation measures are available to the United States, especially as energy prices continue to rise. The Swedish economy performs well as a (relatively) energy efficient economy, suggesting that more efficient energy use will not interfere with the function of the American economy. While we hesitate to give an exact figure we suggest that Swedish methods of energy conservation; including smaller cars, better structures, and more efficient use of process heat, would result in savings of $30 \%$ of the total energy used in the United States (Fig. 10). Thus international energy use comparisons, far from suggesting an inevitable coupling between level of economic activity and energy use, actually suggest ways in which more well being can be wrought from every Btu of fuel and kilowatt-hour of electricity consumed in a given country. 


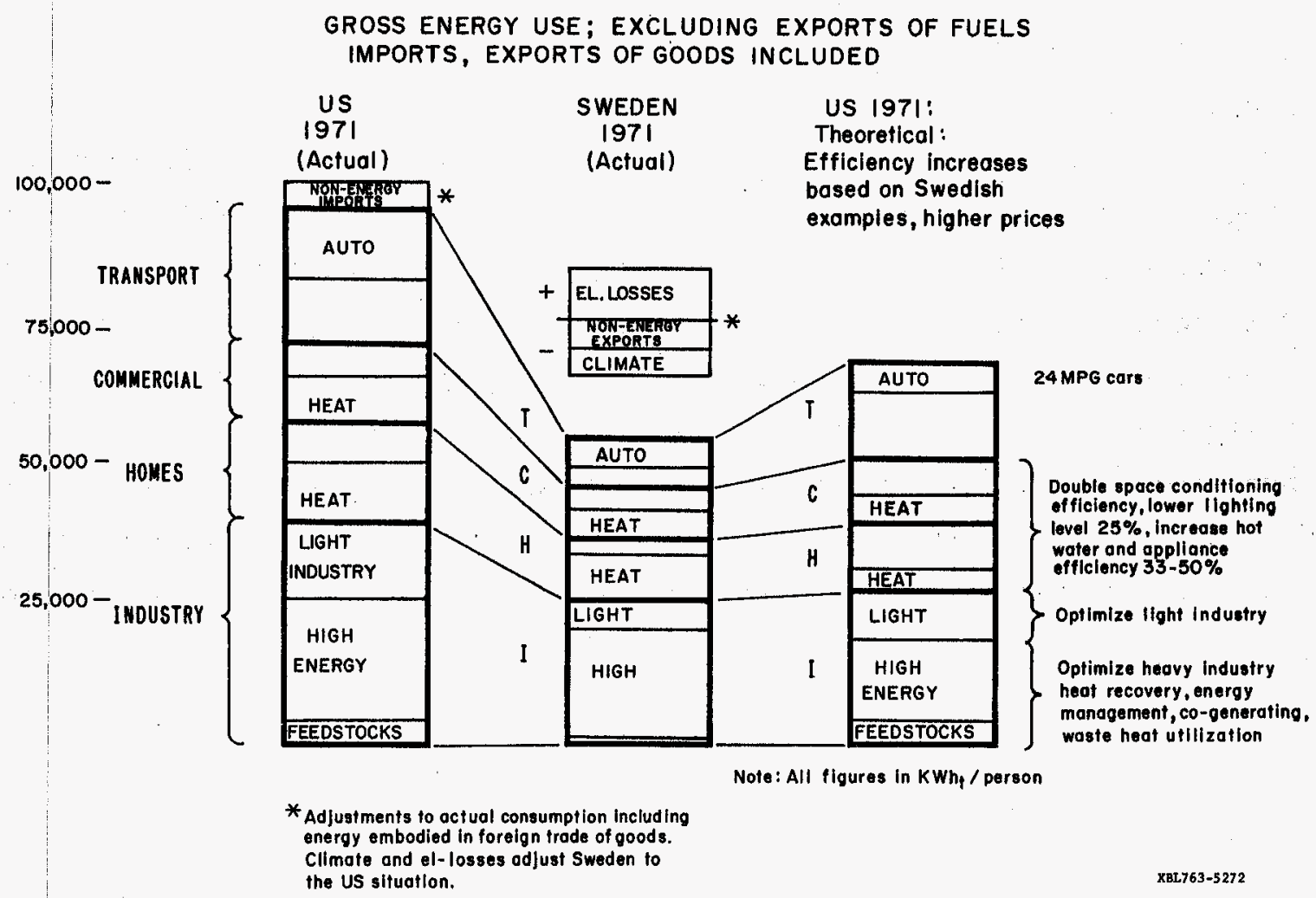

Fig. 10. Summary: U.S. and Swedish energy use, 1971, and U.S. use based on Swedish intensities in industry, space conditioning, autos (mpg); also assumes U. S. Appliance intensity decreases by 33\%, lighting levels decrease by $33 \%$. Freight, airlines, energy harvesting ignored, but higher air conditioning and lighting efficiency factored in. See also (3-5). Lifestyle factors (numbers of appliances, passenger miles) not considered. 


\section{FOOTNOTES AND REFERENCES}

Note: Where a title is listed in English only, it is available in English. Where the listing is in Swedish, it is available only in Swedish.

1. H. R. Linden, Testimony Before the President's Energy Resources Council, Dec. 10,1974 . See also Resource, Economic and Historic Considerations Related to Issue of Energy Policy, 1975. Available from Institute for Gas Technology, Chicago, IL.

2. For a different view of energy and GNP data see D.B. Goldstein and A.R. Rosenfeld, Conservation and Peak Power: Cost and Demand, Lawrence Berkeley Laboratory Report LBL-4438 (1975).

3. M. Ross and R. Williams, Assessing the Potential for Fuel Conservation, Institute for Public Policy Analysis Report 75-02, SUNY, Albany, NY (1975) . (Available from M. Ross, Department of Physics, University of Michigan, Ann Arbor, MI.)

4. L. Schipper, "Energy Conservation: Its Nature, Hidden Benefits, Hidden Barriers," Energy Communications (in press, 1976). See also L. Schipper, "Towards More Productive Energy Use," Annual Reviews of Energy, Vo1. 1, Annual Reviews, Inc., Palo Alto, CA (1)

5. A. Makhijani and A. Lichtenberg, "An Assessment of Material's and Energy Utilization in the U.S.," Environment 14 (5):10 (1971).

6. World Alternative Energy Strategies Project, C. Wilson, Director (communicated by S. Carhart and P. Craig, 1975). Also Comparison of Energy Use in Ten Countries, Resources for the Future, Inc., (communicated by J. Darmstadter, Director).

7. A. Doernberg, Comparative Analysis of Energy Use in Sweden and the United States, Brookhaven National Laboratory Report BNL-20539, Upton, NY, (1975) .

8. Industri Department, Danmarks Energi Forsyning i Fremtiden (Denmark's Energy Supply in the Future), Kobenhaven (1974). See also B. Elbaek, Energi--Energi--Energi Kris, Munksgaard, Kobenhavn (1975).

9. Ministry of Industry, Energiforsyningen in Norge pa Fremtiden (Energy in Norway in the Future), St. Med1. Nr. 100, 0slo (1974). See also H. Parr et al., Energi, Miljф og Samfunn (Energy, Environment, and Society), Norges Naturvernforbund, Oslo (1974).

10. J.D. Parent, Some Comments on Energy Consumption and GNP, Institute for Gas Technology, Chicago, IL (May 1974, revised October 1974).

11. R. Goen and R. White, Comparison of Energy Consumption Between West Germany Germany and the United States, Stanford Research Institute, Menlo Park, CA (1975). Available from GPO.

12. T.D. Mount, L.D. Chapman, and T.J. Tyrre11, Electricity. Demand in the United States: An Economic Analysis, Oak Ridge National Laboratory, Report ORNL-NSF-EP-49 (1973) . Available from NTIS. 
13. W.J. Mead, "Discussion of Dynamic Demand Analysis of Selected Energy Resources by H.S. Houthakker, P.K. Verlager and D.P. Sheehan," Conf, of the Am. Econ. Assoc., New York, NY (1973).

14. Foster Associates, Energy Prices 1960-1970, Ballinger Books, Cambridge, MA (1974).

15. A Pilot Project in Homeowner Energy Conservation, Federa1 Energy Administration and the American Gas Association, Washington, DC (1974). Available from USGPO.

16. Energi Prognos Kommitéen, Energi, 1985-2000, (Energi Prognos Utredningen [EPU]), Ministry of Industry, Stockholm, Available from Allmanna Forlaget, Stockholm (2 vols.).

17. K. Munther, Energi-Förbrukning i Smahus (Energy Use in Single Family Dwellings), Staten Institut for Byggnadsforskning, Report 58, Stockholm (1974). Available from Svensk Byggtjanst, Stockholm.

18. In this and other examples Swedish useage is adjusted to reflect a $60 \%$ fossil-fueled heating (First Law) efficiency.

19. S. Schurr and J. Darmstadter, Energy Use in the U.S. Economy 1850-1970. Resources for the Future, Johns Hopkins University Press, Baltimore, MD (1972).

20. J. Kravis et a1., A System of International Comparison of Gross National Product and Purchasing Power, John Hopkins University Press, Baltimore, MD (1975) .

21. Effektivare Energi Använding (More Efficient Energy Use), Ingenjörs Vetenskaps Akademin (IVA) Med. 181, Stockholm (1975).

22. Some Facts About Sweden, Skandinaviska Enskilda Banken, Stockholm (1974 1975). We use 5.18 $\mathrm{skr}=\$ 1.00$. In 1974 the applicable rate would be approximately $4.30 \mathrm{skr}=\$ 1.00$.

23. Statistiska Arsboken (Statistical Abstract of Sweden), Statistiska Centra1byran (SCB), Stockholm $(1972,-73,-74,-75)$.

24. 1975 U.S. Statistica1 Abstract, Department of Commerce, Washington, DC (1975). Available from USGPO.

25. K. Hultgren, Manniskan och Bilsamhallet (People and the Automobile Society), Pan Nordstedts, Stockholm (1974).

26. L. Ane11 et al., Skal1vi Asfaltera Sverige? (Should We Pave Over Sweden?), Pan Nordstedts, Stockholm (1971). 
27. We use $68^{\circ} \mathrm{F}$ as a base temperature for both countries, and we ignore appliance heat loads, etc. This understates heating differences because appliance use is somewhat greater in the U.S., while insolation in Sweden is sma11 compared to nearly all of the U.S. in the winter. Peak could temperatures are not as low in Sweden as in our North Central, North Midwest, Rocky Mountain, and New England States, but average temperatures are comparable, while the Swedish winter is longer.

28. W. Dupree and J. West, United States Energy Through the Year 2000, Department of the Interior, Washington, DC (1972, updated 1975). Available from GPO.

29. E. Cook, Study of Energy Futures, Environmental Design Research Associates, Chapel Hi11, NC (1975).

30. R. Knecht and C. Bullard, Direct Use of Energy in the U.S. Economy, Center for Advanced Computation Tech. Memo No. 43, University of I1linois, Urbana, IL (1975).

30a. Patterns of Energy Consumption in the U.S. -- 1968, Stanford Research Institute, Menlo Park, CA (1972). Available from GPO.

30b. T. Hoffman et a1., Reference Energy Systems, Brookhaven National Laboratory (1974). Available from NTIS.

31. Verksamheten (Activities), Angpanneföreningen, Stockholm (1971-76).

32. SOS Industri 1970-73 (Sweden's Official Statistics -- Industry), Statistiska Centralbyrån, Stockholm (1972-75).

33. Energiforskning (Energy R\&्षD), 5 vols., Energiprogramkommitteen (EPK), Vo1. A, Energin och Näringslivet (Energy and the Economy), Industridept, A1 lmänna Förlaget, Stockholm (1974).

34. The latest energy use data for Sweden are published as part of the Energy Conservation Bill in the Parliment: Energy-Hushållning (Energy Husbandry), Ministry of Industry, Stockholm (Feb. 1975). See also Energiförsörjningen 1975-1980, Rapport av Stateus industri-verk, Stockholm. Available from Allmänna Förlaget.

35. R. Herendeen and C. Bullard, "U.S. Energy Balance of Trace," Energy Systems in press (1976).

36. E. Hirst, Energy Intensiveness of Passenger and Freight Traffic, 1950-1970, Oak Ridge Nationa1 Laboratory Report ORNL-NSF-EP-41 (1973), Available from NTIS.

37. Estimated Motor Vehicle Travel in the United States, Federal Highway Administration, Washington, DC (1970-75).

38. Nationwide Personal Transportation Survey, Federal Highway Administration, Washington, DC (1970). Available from GPO. 
39. Project Independence: Energy Conservation; Transportation, Federal Energy Administration, Washington, DC (1974), Available from GPO.

40. Regionala Traffikplanering (Regional Traffic Plan), Ministry of Communications, Stockholm (1972). See also Transporter i Sverige (Transportation in Sweden), Ministry of Communications, Report Dsk 1975:4, Stockholm (1974). And see Fact Sheet of Swedish Transportation, Swedish Institute, New York, NY (1973). Available from Swedish Information Service, 825 3rd Ave, New York, NY 10022.

41. Energi: Beredskap i Kristid (Energy: Preparedness During Crisis), Energi Beredskaps Utredningen (EBU), Department of Commerce, SOU 75:61, Stockholm (1975). Available from Allmänna Förlaget, Stockholm.

42. Automobile Facts and Figures, Motor Vehicle Manufacturers Association, Detroit, MI (1975). See also Motor Vehicles and Energy, Motor Vehicle Manufacturers Association, Detroit, MI (1974).

43. K. Austin and K. Hellman, Passenger Car Fue1 Economy, Society of Automotive Engineers, SAE Paper 730790, New York, NY (1973).

44. Motor Traffic in Sweden, AB Bilstatistik, Stockholm (1974075). See also J. U1lén, Bilfakta (Auto Facts), Vo1. 28, Jan U1lén AB, Stockholm (1975).

45. See Ref. 33, Vo1. C, Transport och Samfardse1 (Transportation).

46. Personbilarnas Arliga Körlängd (Yearly Private Car Vehicle-Miles), Statens Vägverk, To 122, Stockho1m (1974).

47. J. Austin and K. Hellman, Passenger Car Fuel Economy as Influenced by Trip Length, Society of Automotive Engineers, SAE Paper 750004, New York NY (1975) .

48. O1jeåret 1974, (Oil Year 1974), Svensk Esso AB, Stockho1m (1975).

49. A. Makhijani and A.J. Lichtenberg, An Assessment of Residential Energy Use in the U.S.A., University of California Engineering Research Laboratory, ERL M-310, Berkeley, CA (1973).

50. J. Moyers, The Value of Therma1 Insulation in Residential Construction, Oak Ridge National Laboratory Report ORNL-NSF-EP-9, Oak Ridge, TN (1972). Available from NTIS.

51. Residential and Commercial Energy Use Patterns, 1970-90, Project Independence Task Force Report, Federa1 Energy Administration, Washington, DC (1974). Additional data from S. Dole of Rand Corporation, J. Moyers of Oak Ridge Nationa1 Laboratory, and Mans Lönnroth of Secretariat for Future Studies, Stockholm.

52. Indeed, the mortgage law of 1957 gave priority to home builders or buyers who intended to insulate beyond the building code minima. A newer program (1975) enables greater subsidies, direct grants, and local testing programs.

53. Sveriges E1konsumtion, 1975-1985, (Swedens Electricity Use, 1975-1985), Centrala Drift Ledningen, Stockholm (1972). 
54. See Ref. 33, Vo1. D, Uppvärmning och Loka1 Komfort (Heating and Space Confort).

55. R. Johnson, and L. Be11, Malmö's Powerplants, Industriverket, Ma1mö, Sweden (1973).

56. J. Meyers et a1., Energy Consumption in Manufacturing, Ballinger Books, Cambridge, MA (1975).

57. Census of Manufacturers (Energy Data for 1971), Department of Commerce Washington, DC (1972). Available from GPO.

58. W. Chern, Electricity Demand by Manufacturing Industries in the U.S., Oak Ridge National Laboratory Report (ORNL-NSF-EP-87, Oak Ridge, TN (1975). Available from NTIS.

58a. E. Hirst, Electric Utility Advertising and the Environment, Oak Ridge National Laboratory Report ORNL-NSF-EP-11, Oak Ridge, TN (1972) .

59. E.P. Gyftopolous et a1., Potential Fuel Effectiveness in Industry, Ballinger Books, Cambridge, MA (1975).

60. S.I. Kaplan, Energy Demand Patterns of Eleven Major Industries, Oak Ridge National Laboratory Report ORNL-TM-4610, Oak Ridge, TN (1974) . Available from NTIS.

61. Energy Conservation in Swedish Industry, Swedish Federation of Industries, (Industriforbundets Förlag, Box 5501, 11485 Stockholm (1974).

62. A. Iveroth and B. Helmerson, Industrin och Energi (Industry and Energy), Swedish Federation of Industries, Industriforbundets Forlag, Box 5501, 11485 Stockholm (1974).

63. U. Norhammer, in speeches to various industry groups published in Swedish by Angpanneforeningen, Stockholm (1975).

64. Catalogues of Back-Pressure (Co-Generation) Systems, with Statistics (in Swedish), Sta1-Laval Co. (1975).

65. Energy Industrial Center, Dow Chemical Co, et a1., National Science Foundation, Office of Energy RơD, Washington, DC (1975).

66. Swedish government hydropower, producing $75 \%$ of the total electricity in Sweden, was financed at commercial interest rates, in contrast to our TVA project.

67. B. Hannon, "Energy Conservation and the Consumer," Science 189 (11 July 1975).

68. F. Felix, "The U.S. Becomes More Energy Efficient," Electrical World (1 December 1975). See also F. Felix, "Greater Use of Electricity Boosts Energy Efficiency," Electrical World (1 November 1975), Felix's results are hard to reproduce, and his "statistics" are carefully scrutinized in an appendix to Ref. 11. 
69. J. Holdren, "Energy and Prosperity," Bul1. At. Sci. (December 1975).

70. E1försörjningen 1973, (E1ectric Energy Supp1y), Statistiska Centralbyrän, Statistska Meddelanden, Nr. 1, 1974:52, Stockholm (1975). 
APPENDIX

\section{DISCUSSION OF ELECTRICITY PRODUCTION AND DISTRICT HEATING}

It is often noted that Sweden is rich in hydropower, an energy source that accounted for approximately $14 \%$ of all energy and $75 \%$ of a11 electricity produced in 1972. Similarly about 35\% of Sweden's fuel-based electricity came from back pressure production. This is accounted in Table A-1.

As the $k W h_{t}$ per capita total in Table 2 suggests, Sweden's energy use would be higher (by about $20 \%$ ) if all electricity were generated at the U. S. rate of approximately $3 \mathrm{kWh} / \mathrm{kWh}$. This Appendix discusses the accounting for hydropower and other statistical difficulties.

Hydropower

Seventy-five percent of Sweden's 1971 electricity supply came from hydropower, Sweden's most important domestic energy source, counted in Swedish statistics (Fig. 3) at $85 \%$ First Law efficiency. Since most of Sweden's hydro resources are in the far north, transmission line losses are greater than in the U. S., per net $\mathrm{kWh}$ e sold.

But simply tripling the net sales of hydropower to final demand, as was done in the $\mathrm{kWh}_{t}$ per capita column in Table 2, can be misleading. This is because the use of electricity, particularly in industry, is stimulated by the low ratio of the price of electricity to the price of fuel. This is, electricity in Sweden cost approximately $0.8 \$ / \mathrm{kWh}$ to heavy users, while fuel oil cost $\$ 0.80$ to $1.00 / 10^{6} \mathrm{Btu}$ (about $0.3 \phi / \mathrm{kWh}$ ), significantly higher than the price of natural gas or coal to most U. S. industries. Had electricity been $85 \%$ thermally generated, as in the U. S., it would have been more expensive, especially since public (as well as private) power is financed in Sweden at prevailing commercial interest rates. Thus we find that electricity utilization in industry and transportation is greater in Sweden than in the U. S., in part because of its low price relative to fuel.

Back Pressure Generation of Electricity

Combined heat/electricity systems in Sweden produce more useful kWh per $\mathrm{kWh}_{\mathrm{t}}$ consumed than purely electrical-thermal plants. In 1971 Sweden consumed fuel amounting to about $4.11 \mathrm{MWh}$ per capita to produce $1.77 \mathrm{MWh}$ per capita of 
Table A-1. Electric power and heat supply in Sweden (1972). ${ }^{\text {a }}$

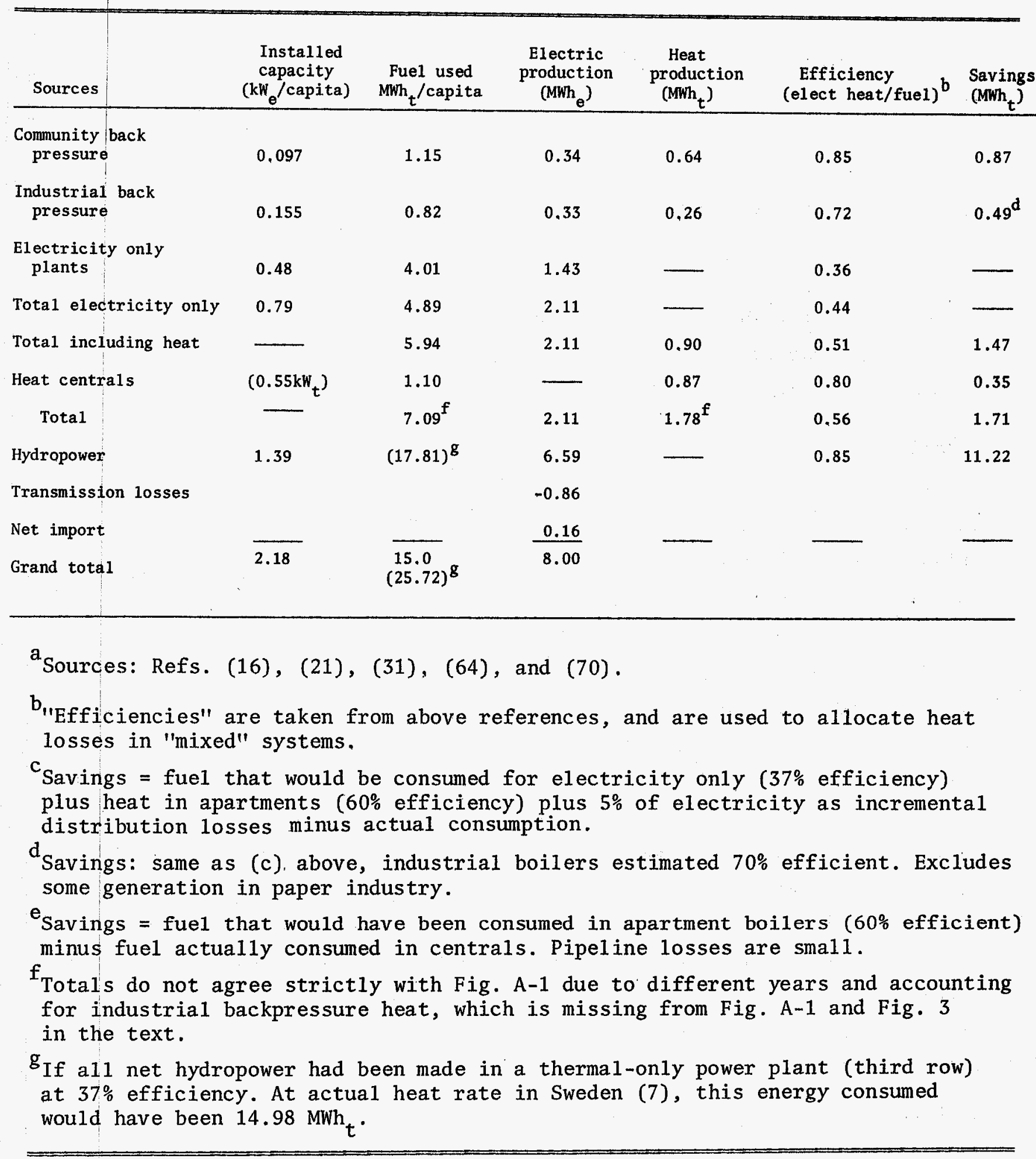


electricity, for a "heat" rate of $2.12 \mathrm{kWh}$ per $\mathrm{kWh}$. This is illustrated in Fig. A-1, in which $0.8 \mathrm{MWh}$ per capita heat-only production is included with about $0.95 \mathrm{MWh}$ per capita included in inputs and about $0.15 \mathrm{MWh}$ per capita in the waste heat figure. If the heat and electricity had been generated separately, about 1.3 MWh per capita additional fuel would have been required, assuming the heat was then produced in central plants, and about $1.5 \mathrm{MWh}$ per capita more if heat had been made in smaller boilers. In fact, half of the back pressure production took place in or near cities, while the other half was located in industries, primarily paper. The heat from these plants is omitted from Fig. A-1.

A combined district heat system is show in Fig. 6 serving $50 \%$ of the needs of Malmö. It can be seen that the utilization of fuel is increased significantly. Swedish statistics (see EPU (16), p. 70) count the efficiency of electricity production as [electricity produced/(total energy consumed - heat used directly/:85)], giving about $78 \%$.

District Heating

The effect of central heat-only plants is included in Fig. A-1; these provide heat for 600,000 dwellings, at $85 \%$ fuel to home (First Law) efficiency, compared to $65 \%$ for boilers in apartments. This saves $5100 \mathrm{kWh}$ per dwelling or $375 \mathrm{kWh}$ per capita. Another $25 \mathrm{kWh}$ per capita is saved by district heating of buildings, for a total savings of about $400 \mathrm{kWh}$ per capita from heat centrals. These savings must be added to those from use of district heat from combined generation.

The Heat Rate in Sweden

Virtual1y all of Sweden's therma1-electric-only capacity $(1.80 \mathrm{~kW}$ per capita in 1972) was built after 1955; thermal efficiencies average $37 \%$ versus $32 \%$ in the U.S. Since co-generation accounted for nearly $35 \%$ of Sweden's thermal generation of electricity in 1972, and since that fraction may remain large during the next decade (63) the "correct" heat rate for Sweden may be imputed to be

[(fuel consumed in electricity-only stations)

+ (fuel consumed in co-generation of electricity and heat)

- (total fuel that would have been required if the heat generated had been produced in heat-only boilers)]

$\div$ [electricity produced]. 


\section{SWEDEN}

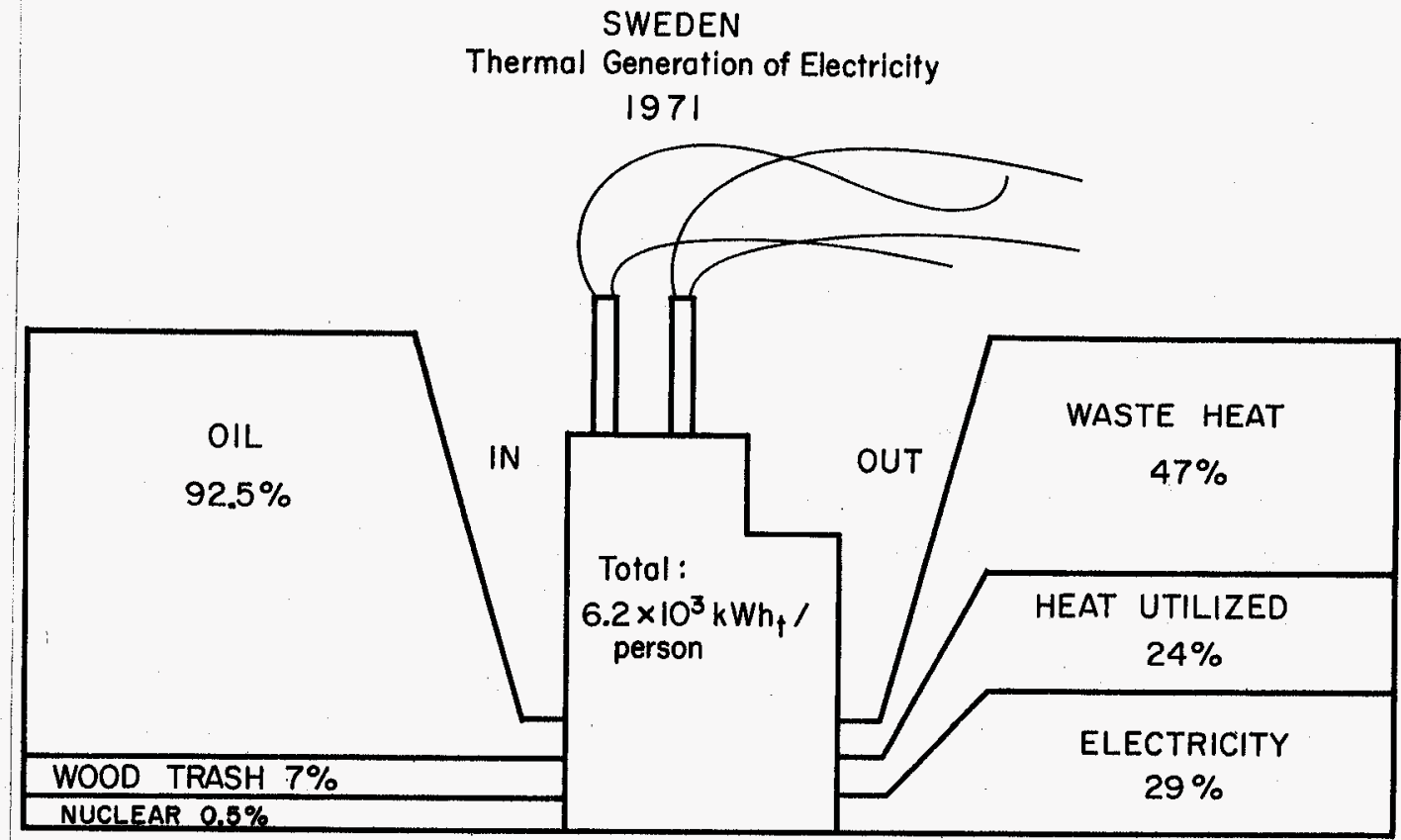

Approximate accounting : Electricity was $67 \%$ condensation only, $33 \%$ back pressure systems. Heat was $50 \%$ district heat only, $50 \%$ back pressure systems.

UNITED STATES

Thermal Generation of Electricity 1971

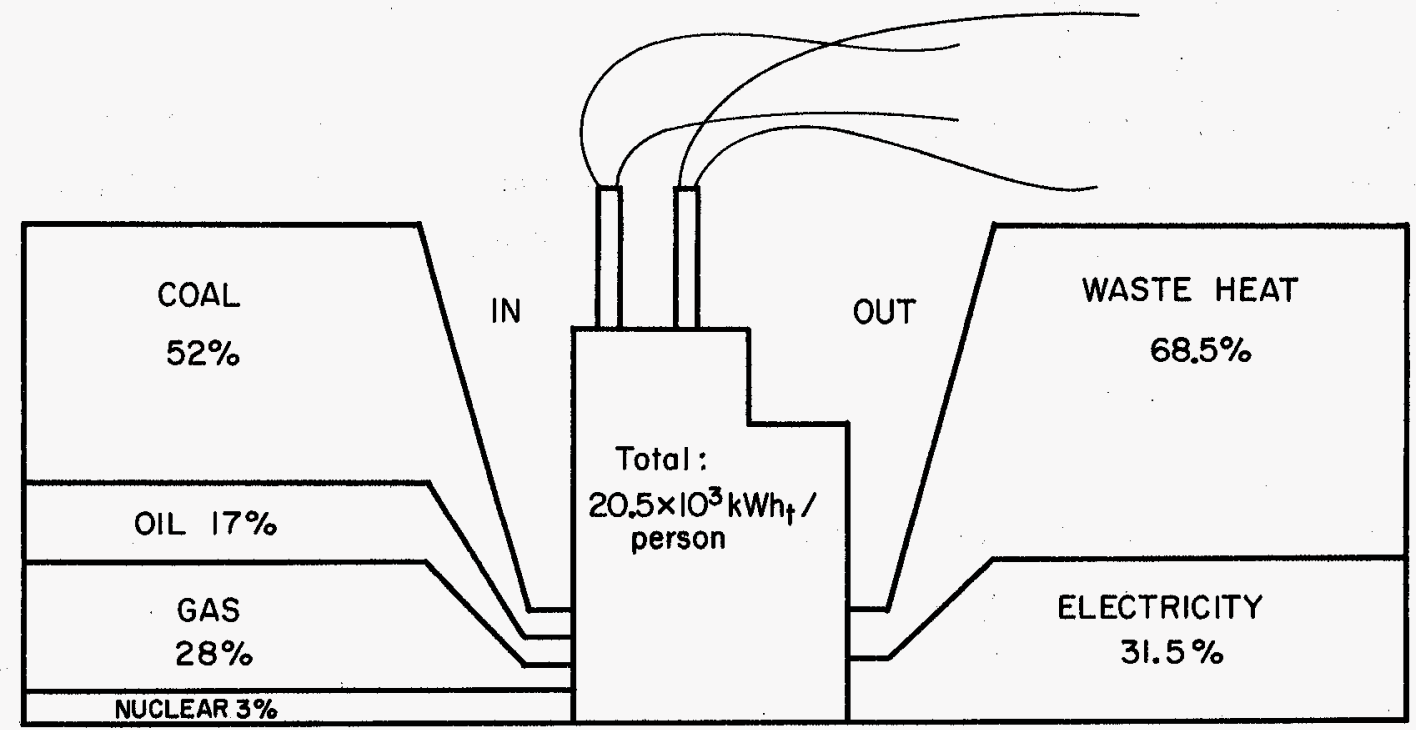

XBL763-5232

Fig. A-1. The use of fuel to produce electricity in Sweden and the U.S.

1971. Taken from Figs. 2 and 3 in the text. Swedish data excludes some process heat supplied to paper and mining industries (500 kWh per capita). U.S. data excludes a sma11 amount of co- and self-generation in industry. Table A-1 presents a more detailed accounting for Sweden. 
This accounting method gives a heat rate of $2.1-2.3 \mathrm{kWh} / \mathrm{kWh}$ depending on how one rates the production of heat. Under this scheme the totals given in Table 2 could be modified so that $k W h_{t}=(k W h-k W h)+2.1(k W h)$. Applying the U.S. heat rate to Swedish hydropower, as was done in Table 2 ( $\mathrm{kWh}_{\mathrm{t}}$ ) raised apparent consumption of energy in Sweden by nearly $20 \%$. Applying the actual thermal heat rate in Sweden derived herein would reduce this increase to about $12 \%$. In any case, the differences in energy use between Sweden and the U.S. still remain significant. 